\title{
Glaucoma control strategies in Sub-Saharan Africa: a review of the clinical and health economic evidence
}

\author{
Andrew F. Smith $(1,2)$ * \\ Guy Negretti $(3,4)$ \\ Aaron Mascaro $(2,5)$ \\ Desta Bokre (3) \\ Helen Baker (3) \\ Kazim Dhalla (6) \\ Ian E. Murdoch $(3,4)$
}

1. Department of Ophthalmology, King's College London, London, England

2. MedMetrics Inc., Ottawa, Canada

3. UCL Institute of Ophthalmology, University College London, London, England

4. Moorfields Eye Hospital, London, England

5. McGill University, Montreal, Canada

6. Dr. Agarwal's Eye Hospital with Abu Baseer Specialist Eye Clinic- Tanzania

* Corresponding author:

MedMetrics Inc.,

Suite \# 747,

1500 Bank Street,

Ottawa, Ontario

Canada, K1H 1B8

Email: Andrew.Smith@ MedMetricsinc.com 


\begin{abstract}
:
Purpose: A review of the effectiveness, costs and cost-effectiveness of detection and treatment strategies for glaucoma control in Sub-Saharan Africa (SSA) was conducted.

Methods: Detailed searches were performed using the Ovid Medline; Ovid Embase; The Cochrane Library; Web of Science; Scopus; and LILACS databases up to September 2016. The key Medical Subject Heading (MeSH) search terms used included: glaucoma, diagnosis, treatment, effectiveness, costs, cost-effectiveness and Sub-Saharan Africa. Effectiveness was measured as the proportion of study participants with an intra-ocular pressure (IOP) less than or equal to $22 \mathrm{~mm} \mathrm{Hg}$.

Results: A total of 5,658 records were examined with 48 papers identified. The sensitivity and specificity of portable instruments or smart phone technologies to detect glaucomatous changes ranged from $58.3 \%$ to $93.8 \%$ and from $82.4 \%$ to $96.8 \%$, respectively. The overall effect size for various glaucoma interventions was: 0.39 (95\% C.I. 0.27-0.54, $\mathrm{I}^{2}=64.85, \mathrm{P}=0.036$ ) for laser trabeculoplasty; 0.56 (95\% C.I. 0.23-0.84, $\left.\mathrm{I}^{2}=85.74, \mathrm{P}=0.001\right)$ for drainage implant devices; 0.66 (95\% C.I. 0.61-0.71, $\mathrm{I}^{2}=0.00, \mathrm{P}=0.402$ ) for medical management; and 0.73 (95\% C.I. 0.65-0.80, $\left.\mathrm{I}^{2}=93.25, \mathrm{P}=0.000\right)$ for all other non-drainage tube surgical interventions, including trabeculectomy surgery and the use of anti-metabolites. The mean annual cost of anti-glaucoma drugs across SSA was US\$ 394, with a mean direct non-medication cost per year of US\$ 54, and a mean surgical cost per year of US\$283.
\end{abstract}

Conclusions: While effective glaucoma control interventions exist their widespread use and diffusion across SSA remains challenging principally due to low per capita income levels and high glaucoma treatment costs.

Word Count: 250

Key words: Glaucoma control, Sub-Saharan Africa, effectiveness, costs, cost-effectiveness, 


\section{Background:}

\section{Magnitude of the problem}

Cumulatively the "Glaucomas" constitute a significant global eye and public health challenge with some 64.3 million persons being affected worldwide in 2013, rising to 76 million by 2020 and 111.8 million by 2040, respectively [1]. Geographically, Quigley et al showed that Sub-Saharan Africa (SSA) was the most adversely affected region and had the highest ratio of glaucoma to adult population of any region on the globe, the figures being $4.32 \%$ of the population in 2010 , rising to $4.39 \%$ by 2020 , respectively [2]. In terms of actual patient numbers, this equates to roughly 6.48 million persons with glaucoma in SSA in 2010 rising to 8.35 million by 2020 [2]. Such a disproportionate burden of glaucoma in SSA is due to a myriad of factors including: a shortage of ophthalmologists - including glaucoma specialists; a lack of knowledge about glaucoma and its treatment; the cost prohibitive nature of treatment; the poor uptake of possible interventions both for screening and detection as well as for medical, surgical treatment and management strategies [3-4]. Similarly, in 2011 Palmer et al, showed that the ratio of ophthalmologists to population across SSA, was a staggering 2.9 per million of population [5]. Additionally, there is the persistent problem of the maldistribution of ophthalmologists throughout many parts of SSA, where an estimated $67 \%$ of ophthalmologists reside in capital cities across SSA, when $62 \%$ of the population of SSA actually lives in rural areas [5-6]. Further compounding the above is the negative impact of low per capita income levels across SSA which make current expensive treatments cost prohibitive for the vast majority of the population. Additionally, chronic under investments in the public healthcare sector, particularly in eye care services throughout much of SSA limit the effectiveness of such glaucoma control strategies as are currently available.

The high cost of glaucoma care in Sub-Saharan Africa 
Eye care services for glaucoma control across SSA are significantly constrained by both high direct and indirect treatment and management costs as well as by low mean Gross National Income (GNI) per capita incomes, which in 2015 amounted to a mean per annum annual income of US\$1,631 across SSA [7]. This is to be contrasted against the high annual medical and surgical cost of glaucoma care across SSA, eye care which if available, is principally the preserve of a tiny wealthy urban minority. In this regard, Omoti et al has calculated that in Nigeria the mean annual medical cost in 2010 for glaucoma was US $\$ 273.47 \pm 174.42$ (range, $\$ 41.54$ to $\$ 729.23$ ) while the mean annual cost of surgical treatment for glaucoma was US\$283.78 \pm 202.95 (range, $\$ 61.33$ to $\$ 592.63$ ) [8]. Thus, assuming that such costs structures may be generalized to the rest of SSA, most patients if they could pay, would part with something in the region of $16 \%$ to $17 \%$ of their annual income solely to treat and manage their glaucoma. Added to these direct eye care costs are the many indirect costs, such as those associated with travel often from rural locations to urban centers for treatment, etc. Not surprisingly, as Adio and Onua have noted, if one adjusts such glaucoma expenditures by income levels, many glaucoma patients across SSA on much lower income levels would actually spend the majority of their monthly income on glaucoma treatments, while those middle-income earners could potentially spend upwards of 50\% of their monthly incomes on glaucoma care [9].

\section{$\underline{\text { Rationale for current research }}$}

Viewed in the above context, it is surprising that, to date, no comprehensive review of the optimal detection and treatment strategies for glaucoma control at a population-based level in SSA has been conducted. This is despite the clear urgency of the problem at least as recognized by the global Vision 2020 coalition on blindness prevention and treatment [10]. It is against precisely this backdrop that the current research project was conceived with the aim of establishing the current evidence base 
surrounding the effectiveness, costs and cost-effectiveness of key glaucoma control strategies at the population-based level across SSA.

\section{Aims:}

Given the imperative of assessing the current evidence base related to glaucoma control strategies in SSA, the scope of this comprehensive review was to examine recent published data on the effectiveness, costs, and cost-effectiveness of various modalities for the detection and treatment of glaucoma in SSA. In particular, the key questions to be answered by the review were:

1) What is the effectiveness of various modalities of detecting and treating glaucoma patients in SSA?

2) What are the direct and indirect costs associated with detecting and treating glaucoma patients in SSA? and;

3) What is the cost-effectiveness of various strategies for the detection and treatment of persons with glaucoma in SSA?

\section{Methods:}

\section{$\underline{\text { Study design }}$}

We performed detailed searches across six (6) biomedical and science databases to retrieve relevant literature for glaucoma control in SSA. The databases searched were as follows: Ovid Medline (1946 to September 2016), Ovid Embase (1947 to September 2016), The Cochrane Library (to September 2016), Web of Science (1900 to September 2016), Scopus (1823 to September 2016), and LILACS (1982 to June 2016). The key search terms used included: glaucoma, diagnosis, treatment, effectiveness, costs, cost-effectiveness and Sub-Saharan Africa. Our search strategy adopted standard Medical Subject Headings (MeSH) terminology conventions such that those terms with synonymous and derivative forms were also captured. Specifically, we used "costs" as a search term and this 
included all alternative terms including "cost* or econom* or afford* or expens* or expend*, where * denotes any number of possible endings, such as "cost", "costed", "costing", "economic", "affordable", "expenses", "expenditure" or "expenditures". To this extent, therefore, our literature search strategy cast a very broad and comprehensive net. All the search results were transferred to an EndNote library where duplicate records were removed and 5658 single records remained.

\section{$\underline{\text { Inclusion and exclusion criteria }}$}

Papers were regarded as worthy for inclusion in our review if they met the selection criteria. These inclusion criteria were: 1) The study must have been written in English, as English remains the main language of publication for the majority of high impact ophthalmology journals; 2) the study must have been conducted on adults $\geq 18$ years of age with a diagnosis of primary open angle glaucoma (POAG), the principal form of glaucoma seen in SSA; 3) the study must have reported on either the effectiveness, costs, and/or cost-effectiveness of a particular glaucoma detection or treatment strategy; and 4) the study must have been conducted in a SSA country as defined by the United

Nations [11]. Conversely, studies were excluded from our review if they met any following conditions: 1) the study was written in a language other than English;2) the study was conducted on a paediatric population, that is, $<18$ years of age; 3 ) the study examined a type of glaucoma other than POAG; 4) the study occurred in an African country outside of SSA; and 5) the study did not specifically mention the effectiveness, costs, and/or cost-effectiveness of the various glaucoma detection and treatment modalities in the title of the retrieved publications.

Identification and selection of studies

In order to ensure the comprehensiveness of our review, several quality control steps were followed. These included reading the titles and abstracts of all retrieved papers. Initially, this was conducted by a single member of the research team (GN). Papers were excluded after a close review of the abstract 
only if it could be ascertained that they did not meet the inclusion criteria or if any of the exclusion criteria were satisfied. Subsequently, a full copy of the paper was obtained and reviewed in detail by a further two members of the research team (AFS and AM) to ensure that the study met the inclusion criteria.

\section{Data abstraction and reviewing strategies}

Data were extracted from the relevant publications and entered into an Excel based spreadsheet to keep track of all relevant parameters and references. Initial search strategy results were generated in September 2016, however, the initial review occurred over the period from October 2016 to January 2017 (GN, DB, AFS, HB, KD and IM). Between February and April 2017, the detailed extraction of the key data relevant to the review was completed (AFS and AM) and preparation of the final results occurred between May and July 2017 in collaboration with the full research team (AFS, GN, AM, IM, DB, KD and HB). Papers were graded using standardized levels of evidence (1 through 5) specifically developed for conducting systematic reviews in evidence-based medicine [12]. In this regard, Level 1 evidence generally denotes a well-controlled blinded randomized clinical trial, the so-called "Gold standard" in clinical research studies; Level 2 evidence typically refers to cohort or observational studies; Level 3 evidence represents case-control studies; Level 4 evidence corresponds to case-series reports; and Level 5 evidence is characterized as so-called "expert" opinions and is regarded the least rigorous form of all evidence-based reviews [12].

Further, for all articles included for review, several key criteria were abstracted including: (1) the study author; (2) the year of publication; (3) the country of study location; (4) the relevant healthcare setting; (5) the number of eyes involved in the study; (6) the type of intervention evaluated; (7) the effectiveness measure used; (8) the relative effectiveness of the intervention of interest; and (9) the quality of the study conducted in terms of levels of evidence. For articles reporting on costs and cost- 
effectiveness of various detection and treatment modalities, the additional criteria of the direct and indirect costs along with measures of cost-effectiveness were also abstracted from the articles reviewed.

\section{Quality Assessment and Effect Size Measures}

Although not formally measured, assessment of the quality of the papers included for review was performed to ensure that it was carried out in a robust and comprehensive manner. This was accomplished by determining if the papers included for review addressed a central research question related to the current review and whether the findings from the reviewed paper followed logically. In addition, all papers included in the systematic review were independently reviewed by two members of the research team (AFS and AM) to ensure a high degree of internal validity in the key findings and to reduce the potential for bias in the findings from papers, particularly those from nonrandomised observational studies which were included as part of the overall systematic review [12].

Simultaneously, key effect measures from individual papers included in the review were extracted for each of the three key areas, namely, effectiveness measures, cost components, and measures of cost-effectiveness. In the case of effectiveness measures, these were further stratified according to the type of detection or treatment strategy reported on. In the case of papers measuring the effectiveness of treatment strategies for glaucoma in SSA, the primary effectiveness parameter measured was intra-ocular pressure (IOP), specifically an IOP $<22 \mathrm{mmHg}$. Costs and costeffectiveness measures were reported in relevant currencies and using standardised cost-effectiveness measures, specifically the cost per disability adjusted life year (DALY) averted.

\section{$\underline{\text { Statistical Analyses }}$}

The statistical analysis of pooled data around the effectiveness of various treatment options for glaucoma in SSA was performed in order to determine the heterogeneity, that is, the degree of 
variation in the findings in study outcomes between various studies reviewed. The effect measures from these aggregated studies were examined to determine the degree of heterogeneity or the "noncombinability" of the pooled results. Heterogeneity was assessed using both Cochran's Q and $\mathrm{I}^{2}$ statistics. In this regard, the Cochran's Q statistics was calculated as the weighted sum of the squared differences between individual study effects and the pooled effect across various studies, where $Q$ is distributed as a chi-squared statistic with $\mathrm{k}$ (number of studies) minus 1 degree of freedom. Thus, when the number of studies is small, Q has a low power as a comprehensive test of heterogeneity, while conversely when the number of studies is large Q tends to have too much power as a test of heterogeneity (13-15). The $\mathrm{I}^{2}$ statistic was also calculated as it is regarded as an improvement on the Q statistic and measures the proportion of the total variation that occurs within trial heterogeneity and thus the $\mathrm{I}^{2}$ statistic is independent of the total number of trials involved and can be used to understand the consistency of the findings across meta-analyses of data (15-16). As such, an $\mathrm{I}^{2}$ value of $0 \%$ denotes a complete lack of heterogeneity, while values of $25 \%, 50 \%$ and $75 \%$ denote a low, medium and high degree of heterogeneity, respectively. Both the $\mathrm{Q}$ and $\mathrm{I}^{2}$ statistics were calculated using a dedicated statistical software package, Comprehensive Meta-Analysis Version 3 (Biostats Inc. () www.meta-analysis.com) and the overall the significance threshold was set at $\mathrm{P} \leq 0.05$ [17]. Lastly, a random effects model was used to analyse the studies included in the review, as the results were likely to vary not just due to sampling errors, but also due to underlying variability in the population of effects as well [17].

\section{Results:}

\section{$\underline{\text { Search strategy yield }}$}

As presented in Figure 1, a total of 5658 records were initially examined and on the basis of the strict inclusion and exclusion criteria this was reduced to a total of forty-eight (48) relevant papers being identified for final review. In terms of the time dependence of the research conducted, it is worth 
noting that as Figure 2 reveals, $85 \%(n=41)$ of the studies included for review were conducted since the turn of the current century, with the remaining $15 \%$ of studies reviewed $(n=7)$ being conducted prior. Moreover, the majority of the papers included in the review, that is $92 \%(n=44)$ reported on either the effectiveness of various glaucoma interventions $(n=33)$, or on glaucoma detection and screening strategies $(n=11)$. Less than a handful of papers $(n=4)$ focused on the costs or costeffectiveness of glaucoma control strategies in SSA.

\section{Search strategy by level of evidence}

Figure 3 reveals the distribution of the reviewed studies according to the level of evidence of the papers using standardized grading criteria for conducting evidence based reviews [12]. As can be seen, the vast majority of the papers reviewed, some $83 \%(n=40)$ were graded as Level 3 (case control studies) or as Level 4 (case series studies) in terms of evidence-based criteria. The remaining $17 \%$ $(n=8)$ of the papers reviewed were graded as Level 1 (RCT) or Level 2 (Cohort or observational studies). No Level 5 studies which are based solely on expert opinion were available for analysis.

\section{$\underline{\text { Glaucoma detection strategies }}$}

Table 1 presents the findings related to the eleven papers on detection strategies which were reviewed. Only one paper reporting the ascertainment of a family history of glaucoma as a detection strategy for glaucoma in SSA met the Level 2 criteria for evidence-based reviews. Sixty-three percent of papers $(n=7)$ met Level 3 criteria for evidence-based reviews for a range of detection strategies ranging from the use of simple measuring tests of common ocular features (pupil size, anterior chamber depth, etc.) as well as the degree of agreement between various cadres of medical personnel of such ocular features to screen for optic nerve cupping using a direct ophthalmoscope by calculating cup to disc ratios; the relative extent of visual field loss using simple optical kinetic visual field tests, 
etc. The remaining papers $(n=3)$ were graded at Level 4 for evidence, and report on studies evaluating devices for measuring IOP and imaging the optic nerve via mobile phone technologies, or the relative success of outreach clinics to detect early glaucomatous changes using such relatively simple ocular measuring devices.

It is interesting to note that studies reporting on detection strategies for glaucoma in SSA were nearly equally split between those conducted in primary $(n=4)$ versus tertiary $(n=5)$ eye care settings, with a further two studies conducted in a secondary eye care setting or within the context of a stand-alone eye study. This is relevant as potentially successful strategies for detecting glaucoma should be as community-based as possible in order to detect and refer those most likely to benefit from observation and/or the initiation of treatment interventions. Digital palpation of the eyeball and examination of the pupils in a primary eye care setting had sensitivity values $<80 \%$ for detecting glaucoma [20] while a simplified visual function test which could be conducted on $90 \%$ of patients in primary eye care in SSA showed good performance and correlation to the size of the optic disc cup, a measure of glaucoma injury [26]. Another paper reported no difference in agreement $(\mathrm{p}=0.98)$ between the vertical cup to disc ratio obtained via a dilated pupil fundus camera eye examination and a smart phone image capturing system under field conditions [27]. There was also very good agreement in terms of detecting cup to disc ratios using an ophthalmoscope amongst a range of eye care personnel (kappa range 0.75-0.92) in a primary eye care setting [23]. In both a primary and tertiary eye care settings, the sensitivity and specificity of detecting glaucomatous visual field loss using the OculoKinetic Perimetry Glaucoma Sreening Test (OKPGST) was found to be 93.8\% and 96.8\%, respectively [22]. Other screening tests reported on in a tertiary care setting included the Peripheral Anterior Chamber Depth (PACD) which had a sensitivity of $77.8 \%$ and a specificity of $82.4 \%$ and the Central Anterior Chamber Depth (CACD) test with a sensitivity of $58.3 \%$ and a specificity of 
$96.1 \%$ [21]. Given the wide range of effect sizes measures no statistical analysis was performed to determine the degree of heterogeneity among the papers reported in Table 1.

\section{$\underline{\text { Effectiveness of Glaucoma Interventions }}$}

As can be seen from Table 2, four broad glaucoma intervention strategies were identified during the review including: i) medical management $(\mathrm{n}=2)$; ii) drainage implant surgical intervention $(\mathrm{n}=3)$; iii) laser treatment ( $\mathrm{n}=4)$; and iv) all other non-drainage tube surgical interventions, including trabeculectomy surgery and the use of anti-metabolites $(n=24)$. In the case of the medical management of glaucoma in SSA, the pooled effect size was found to be 0.66 (95\% C.I. 0.61-0.71, $\mathrm{Q}=0.70, \mathrm{I}^{2}=0.00, \mathrm{P}=0.402$ ) although this was based on only two studies and is unlikely to be representative in nature. Analysis of the pooled effect size for surgically implantable glaucoma drainage devices revealed a mean effect size of 0.56 (95\% C.I. $0.23-0.84, \mathrm{Q}=14.02, \mathrm{I}^{2}=85.74$, $\mathrm{P}=0.001$ ) indicating high degree of heterogeneity, albeit on a relatively small number of papers reviewed. With regards, to laser interventions for controlling glaucoma, principally laser trabeculoplasty, the mean effect size was found to be 0.39 (95\% C.I. $0.27-0.54, \mathrm{Q}=8.54, \mathrm{I}^{2}=64.85$, $\mathrm{P}=0.036$ ) again denoting a moderate degree of heterogeneity across the papers reviewed. Most striking, perhaps, in terms of effectiveness of intervention strategies for glaucoma control, were those papers reporting on surgical interventions, including trabeculectomy surgery with the use of antimetabolities which had a combined pooled effect size 0.73 (95\% C.I. $0.65-0.80, \mathrm{Q}=340.54, \mathrm{I}^{2}=93.25$, $\mathrm{P}=0.000$ ) again yielding a high degree of heterogeneity across the studies reviewed. Figure 4 graphically presents the effect sizes from each of the papers $(n=24)$ reporting on the surgical intervention strategies for controlling glaucoma among the papers reviewed.

\section{$\underline{\text { Cost of Glaucoma }}$}


Table 3 details the breakdown of those papers reporting on the costs of glaucoma care in SSA. As can be seen, the mean annual cost of anti-glaucoma drugs across SSA was US\$ $394(n=3)$. Similarly, the mean direct non-medication costs per year incurred by glaucoma patients in SSA was estimated to be US\$ $54(n=1)$, while the mean surgical costs per year were US $\$ 283(n=1)$. With respect to indirect costs, particularly those directly related to seeking treatment for glaucoma, including patient transportation to and from eye care professionals, lodging costs, the cost of food and sundries, the mean aggregated indirect costs per year incurred by persons with glaucoma and seeking care for their glaucoma amounted to 872 USD (n=2). The authors of these studies did not, however, differentiate indirect costs in detail, though it is likely that the lion's share was associated with travel and transportation from rural areas to urban centres offering glaucoma care and a smaller proportion being spent on local housing and sustenance, including food and sundries. Lost productivity costs due to reduced or underemployment due to time lost from work due to glaucoma and seeking care were not captured in either of these two papers.

\section{$\underline{\text { Cost-Effectiveness }}$}

In Table 4, the sole paper reporting on the cost-effectiveness of various strategies to control glaucoma in Ghana is presented. It is important to note that the paper was entirely based upon a computer simulation model for the entire population of Ghana and did not include actual measures of ocular health status. Nevertheless, this study did explore a range of strategies including: i) incident case identification; ii) syndromic self-referral by patients with mild visual impairment; and iii) universal glaucoma screening for the entire population of Ghana at ages 45, 55, 65, 75 and 85 [63]. The cost

per DALY averted for each of these three options was found to be: i) 6,896 USD; ii) 3,947 USD and iii) 13,504 USD, respectively [63]. A further treatment strategy of providing one-time laser surgery 
resulted in a cost per DALY averted of: i) 1,771 USD; ii) 1,407 USD and iii) 9,808 USD, respectively [63].

\section{Discussion:}

\section{Caliber of the Evidence}

Overall, our literature search found that a preponderance of the evidence on the outcome of various strategies for screening and treating or controlling glaucoma were of poor to average quality with only a total of four RCTs (Level 1 evidence) studies being reported. The remaining studies reviewed consisted of Level $2(n=4)$, Level $3(n=22)$ and Level 4 evidence $(n=18)$ studies across a range of detection and intervention strategies. Papers included for review had sample sizes ranging from 12 eyes [37] to 484 eyes [18] and up to 864 patients [20]. Papers reporting on detection of glaucomatous changes showed generally good sensitivity and specificity, as well as good observer agreement across a range of eye care professional for detecting key glaucomatous features using simple instruments and or smart phone technologies.

\section{$\underline{\text { Screening and detections strategies }}$}

A number of papers reviewed reported high sensitivity and specificity values for detecting glaucomatous changes and a high degree of agreement across a range of eye care professional for detecting key glaucomatous features using simple instruments and or smart phone technologies in SSA. Such portable screening technologies may be particularly helpful in screening for glaucoma in remote rural locations across SSA. In this regard, for example, Thomas et al recently showed that tele-glaucoma screening in a sparsely populated rural Canadian context is highly cost-effective, principally owing to the high patient travel costs associated with accessing ophthalmologists and additional waiting room costs [64]. In particular, the authors of this Canadian study demonstrated that tele-glaucoma screening saved CDN \$27, 460 for each additional quality adjusted life year (QALY) 
gained, well below the CDN \$40,000 cost per QALY threshold, and that over the long term, teleglaucoma screening prevented $24 \%$ cases of glaucoma blindness after 30 years [64]. While the finding that such tele-glaucoma screening techniques are promising and have been deemed to be costeffective in Canada, more research is needed to determine if such tele-glaucoma technologies could be sufficiently adapted to SSA to be deemed to be equally cost-effective, such as perhaps via the use of low-cost mobile phones with retinal images sent to regional reading centres across SSA for grading.

In urban areas across SSA, recent data from India suggests that traditional in person eye examinations for glaucoma screening may be equally cost-effective, particularly if conducted in the 40-69 years age group and if implemented in the urban areas [65]. In practice, therefore, it is likely that the optimal glaucoma screening strategy for SSA and other low-income regions is likely to consist of a combination of tele-glaucoma solutions deployed in rural locations and traditional in person eye examinations in high density population urban centers across SSA and other regions where the burden imposed by glaucoma is particularly onerous [66].

\section{Effectiveness of glaucoma interventions}

Having detected and referred a glaucomatous patient for treatment, a number of effective medical and surgical interventions have been evaluated in SSA and represent a range of currently available treatment options. The reported effect size from the papers reviewed for medical therapies in SSA was found to be 0.66 (95\% C.I. 0.61-0.71). This figure closely corresponds to data from a recent meta-analysis for anti-glaucoma drugs for the medical management of glaucoma which found that among all trials comparing any topical anti-glaucoma drops versus placebo or untreated subjects there was clear evidence of a positive treatment effect on visual field protection (odds ratio 0.62 , 95\% C.I. 0.47 to 0.81 ) [67]. The use of anti-glaucoma medications, while expensive, represents the first line 
treatment option throughout most high-income economies. Across SSA, however, as already discussed, anti-glaucoma medications are often very expensive and too cost prohibitive to be widely used, except by the wealthy urban elites. Other surgical control options might offer greater promise in this regard in the long-term control of glaucoma across SSA.

In terms of laser trabeculoplasty among studies conducted in SSA, this was found to have an effect size of 0.39 (95\% C.I. 0.27-0.54) while drainage implant devices had an effect size of 0.56 (95\% C.I. 0.23-0.84) for studies conducted in SSA. When compared to the international literature, the data suggests that fifty percent $(50 \%)$ of diode laser treatment eyes and $58 \%$ of argon laser treated eyes were successful in maintaining an IOP $<21 \mathrm{~mm} \mathrm{Hg}$ after 5 years [68] Similarly, a number of studies have shown that if laser trabeculoplasty (LTP) was given as the initial treatment, up to half of the patients did not require medical treatment for up to 1-2 years afterwards [69-70]. Thus, the pooled effect size for laser trabeculoplasty from our review was roughly in line with that reported in the international literature. In the case of drainage implants, the international data point to a relative survival of a functioning drainage device in $71 \%$ of eyes operated on for high IOP at 5 years [71]. Interestingly, in a randomized clinical trial comparing tube shunt surgery with trabeculectomy, it was found that the cumulative probability of failure during 5 years of follow-up was $29.8 \%$ in the tube group and $46.9 \%$ in the trabeculectomy group $(\mathrm{P}=0.002$; hazard ratio $=2.15 ; 95 \%$ confidence interval $=1.30$ to 3.56) [72]. Overall, our review found the effect size of all glaucoma surgical interventions, including the use of anti-metabolities yielded an effect size of 0.73 (95\% C.I. 0.65-0.80). This is in keeping with success rates derived from other studies on the long-term outcome of glaucoma surgery in terms of IOP. A Scandinavian study, for instance, found that according to the Kaplan-Meier survival curve, success rates defined as an IOP $<21 \mathrm{~mm} \mathrm{Hg}$ were $82 \%$ at 1 year, $70 \%$ at 2 years, $64 \%$ at 3 years and $52 \%$ at 4 years, respectively [73]. 
In the context of SSA, while non-drainage glaucoma surgical interventions, such as trabeculectomy surgery were shown to have the greatest effect size of 0.73 , they require a high degree of training to attain high quality outcomes. Anti-glaucoma medications come a close second with an effect size of 0.66, however, as has been noted, at present they are cost prohibitive for most people with glaucoma in SSA. Next are the use of drainage implant devices and laser trabeculoplasty with an effect size of 0.56 and 0.39 , respectively. It is probable too that as surgical skills and capacity are increased, the success rates for such surgical options for controlling glaucoma in SSA could be further improved upon. Such an approach is, however, dependent on the creation and maintenance of high calibre surgical training centres and on the provision of affordable domestic or imported drainage implant devices across SSA, both not inconsequential essential conditions. Indeed, in reviewing these options, it is clear that efforts to increase glaucoma surgical capacity and access to low cost generic antiglaucoma medications are two desirable glaucoma control strategies likely to yield significant results across SSA. In particular, increasing glaucoma surgical capacity may also have the additional benefit of increasing the overall capacity to perform both drainage implant and laser trabeculectomy surgery.

\section{Cost of glaucoma care}

Despite being listed as essential medications on the WHO Model List of Essential Medicines, antiglaucoma medications such as acetazolamide, latanoprost, pilocarpine and timolol remain cost prohibitive for many patients with glaucoma in SSA [74]. The high cost of anti-glaucoma medications and glaucoma surgery is not unique to SSA and many other low-income countries also face these same economic barriers. In India for example, it has been calculated that expenditures on antiglaucoma medications ranged from $0.3 \%$ among high income earners to $123 \%$ of glaucoma patient's gross monthly income among those on the lowest income levels [75]. It was also found that the total cost, including travel, lodging costs and lost wages of patients as well as accompanying persons 
ranged from $1.6 \%$ among high income earners to $137 \%$ of the monthly income among low income earners in India [75]. Moreover, in the same study an overwhelming $92 \%$ of patients were not covered by any insurance plan/government reimbursement for their glaucoma treatment [75]. The situation is much the same in Mexico City where it was reported that the monthly economic burden of treating and managing their glaucoma was greatest in the lowest income group (61.5\% of monthly income) and lowest among those on the highest income levels (7.9\% of monthly income) [76]. In this respect, a recent study in the United States concluded that: "Although a small part of the total cost of glaucoma care, non-medical 'out-of-pocket' costs constitute a substantial non-covered medical expense to most patients in the United States" [77]. The paper further suggests that non-medical or 'out-of-pocket' patient expenditures may have a greater effect on patient adherence to office appointments than the direct medical costs [77]. The authors emphasise that clinicians should consider these additional 'outof-pocket'expenses when determining the frequency of follow-up care for glaucoma patients [77]. A possible solution, perhaps, to combating the high costs of anti-glaucoma medications and surgeries across SSA may lie in developing low cost generic anti-glaucoma medications and devices within SSA or to import these from elsewhere, such as from excellent low-cost alternatives now being manufactured in India (e.g. The AuroLab Aqueous Drainage Implant (AADI) with a retail price of US\$ 60) [78]. Such low-cost drainage implants could be further bolstered by providing glaucoma patients with favourable financing options to spread out the large upfront cost of glaucoma surgery over time. Finally, surgical training costs could be reduced by developing regional surgical training programmes based in strategic locations across SSA in order to improve the overall quality and quantity of glaucoma surgery available across SSA.

\section{Cost-effectiveness of glaucoma care}


As noted above, the sole study reporting on the cost-effectiveness of glaucoma control strategies for SSA, found that the overall cost-effectiveness of screening for glaucoma was US $\$ 6,896$ per DALY averted, with additional cost for a one-time laser treatment US \$ 1,771 per DALY averted [63]. To put these figures into context, it is generally asserted that those interventions which cost less than three times the average per capita annual Gross Domestic Product (GDP) in a given country are deemed to be cost-effective, while those interventions which cost less than a particular country's per capita annual GDP are considered to be highly cost-effective [63]. In reality, of course, there are a myriad of health interventions all competing for adoption and implementation subject to funding constraints. Calculating the relative cost-effective of various interventions using the cost per DALY approach is, therefore, closely tied to the prevailing budgetary constraints operating within any given country. Thus, assuming that the per capita GDP for Ghana in 2011 was US\$ 1,575, it is likely that laser surgery for glaucoma is highly cost-effective, while screening for glaucoma is not at all cost effective [79]. Caution, however, should be exercised in extrapolating this limited computer simulation across the whole of SSA and more real-world data would help immensely in confirming or invalidating such findings. This is in sharp contradistinction to glaucoma control strategies from a substantial number of publications from outside of SSA which have showed that screening as well as medical and surgical interventions are generally cost-effective particularly given the often large personal and societal costs associated with vision loss and blindness due to glaucoma [80-81]. The difficulty in comparing our findings to those from studies outside of SSA is, of course, that the healthcare systems of high income economies have completely different healthcare and social care costs as well as completely different eye care infrastructure systems in place than most of SSA.

\section{$\underline{\text { Study Limitations }}$}


A key limitation of the present study is the fact that most studies included for review were relatively poor grade in terms of rigorousness, with only four papers being well controlled randomized clinical trials (Level 1 evidence) and a further four papers being either cohort or observational studies (Level 2 evidence). In addition, relatively few of the studies were conducted in a primary eye care setting $(n=5)$. Both these factors necessarily impose severe limitations on the generalizability of the current review. Nevertheless, they do serve to highlight the deficiencies in the current evidence-base which attends the whole area of how best to manage and control glaucoma across SSA and in a cost-effective manner. In addition, the review found a greater number of papers which reported on the effectiveness of various glaucoma detection and treatment interventions, and relatively few papers which reported on the costs, or cost-effectiveness of glaucoma control strategies across SSA. Both cost and costeffectiveness data while available was of extremely limited value and future studies should be geared towards redressing this lack of high quality health economic data comparing various glaucoma control strategies across SSA.

\section{$\underline{\text { Recommendations and future research }}$}

Although a limited number of studies have demonstrated the effectiveness of glaucoma detection and treatment interventions in a SSA context, to date no real-world comprehensive cost-effectiveness analyses have been undertaken. Rather, cost-effective computer simulation modelling from Ghana has suggested that treating glaucoma is more likely to be cost-effective than instituting populationbased screening measures. What this single modelling study fails to take into account is the high direct and indirect costs associated with glaucoma treatment across SSA, particularly relative to low per capital income levels. It is imperative, therefore, that much needed research to collect real-world health economics data on different glaucoma control strategies are also accompanied by policies aimed at reducing the costs of glaucoma treatment across SSA. 
It is tantalizing, perhaps, to speculate about what sort of optimal glaucoma control policies might be advanced to effectively tackle glaucoma across SSA. Certainly, greater specialized glaucoma surgical training programmes could train more glaucoma surgeons and SSA governments could impose wage and price controls on glaucoma treatments and medications to make treatment more affordable, or greater public-sector investments in eye health could be made, but all options come at a cost. In fact, most ophthalmologists currently working across SSA work in the private sector and it will be imperative to ensure that there is "buy in" from the existing if largely private eye care infrastructure across SSA. The real challenges ahead lie not in not knowing what to do to control glaucoma from a technical perspective, but rather, as is often the case, in translating the evidence into practice given the prevailing political, economic, clinical, professional and other constraints operating across SSA. In the final analysis, only if SSA governments and ophthalmologists are truly willing to invest in expanding the public eye care sector, will a more robust and sustainable long-term way forwards be found to improve overall glaucoma control efforts across SSA. 


\section{Figures:}

\section{Figure 1: Literature search Yield}

Conducted searches across six (6) literature databases

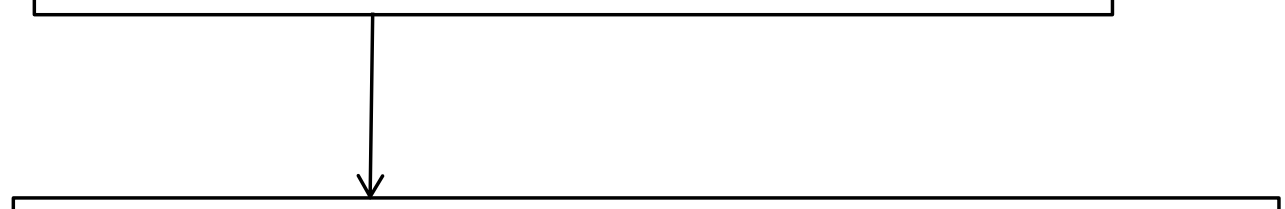

Transferred the records from these searches to EndNote program

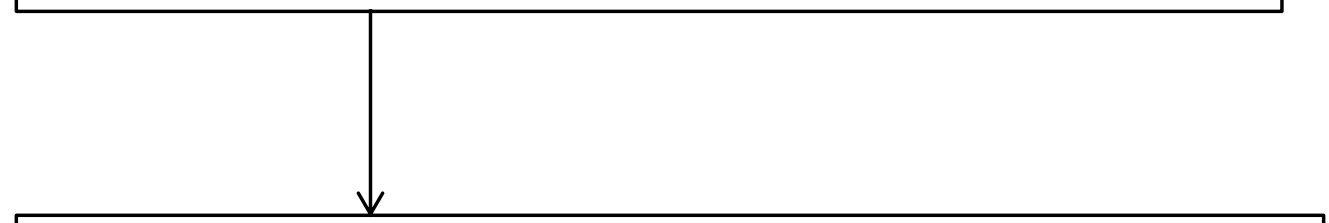

Removed duplicates using the EndNote, yielding 5658 single records

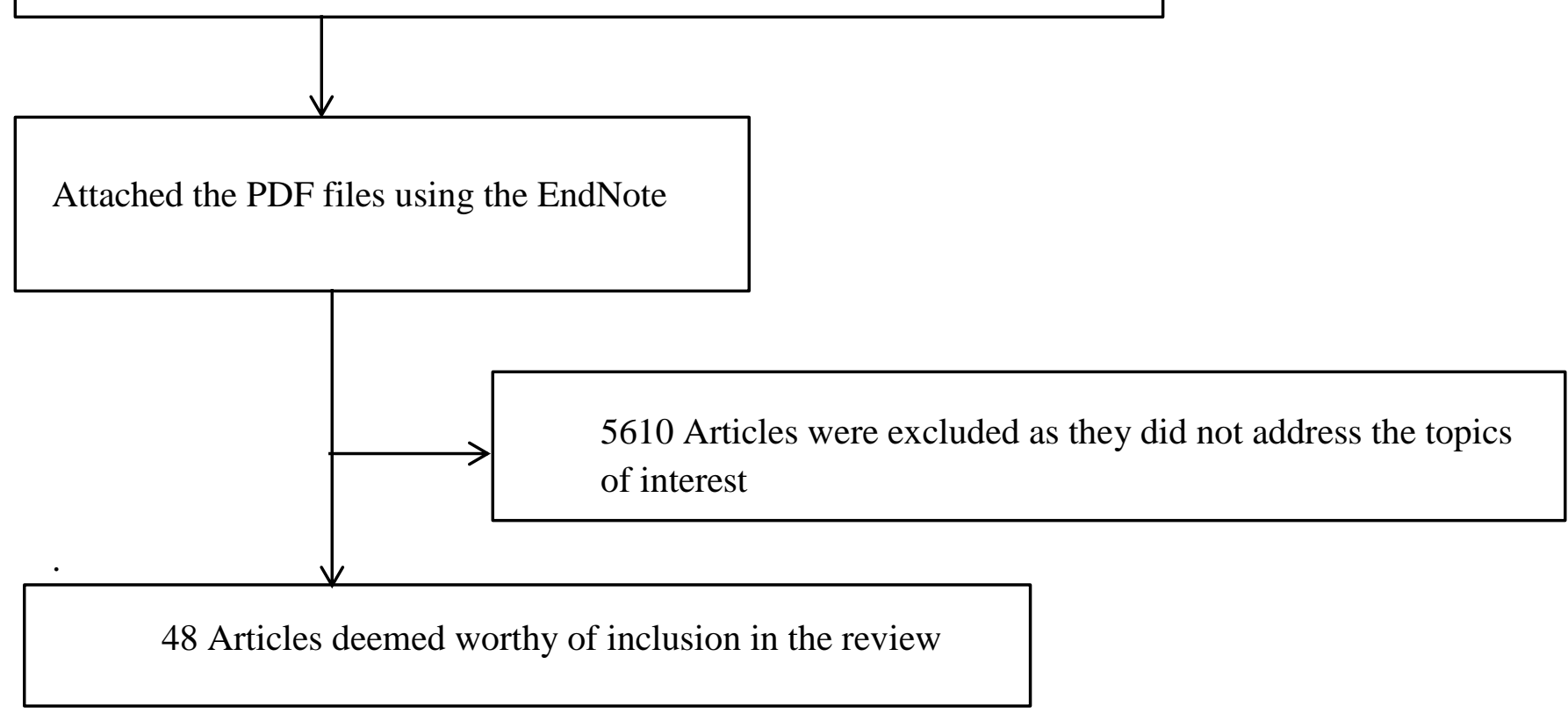




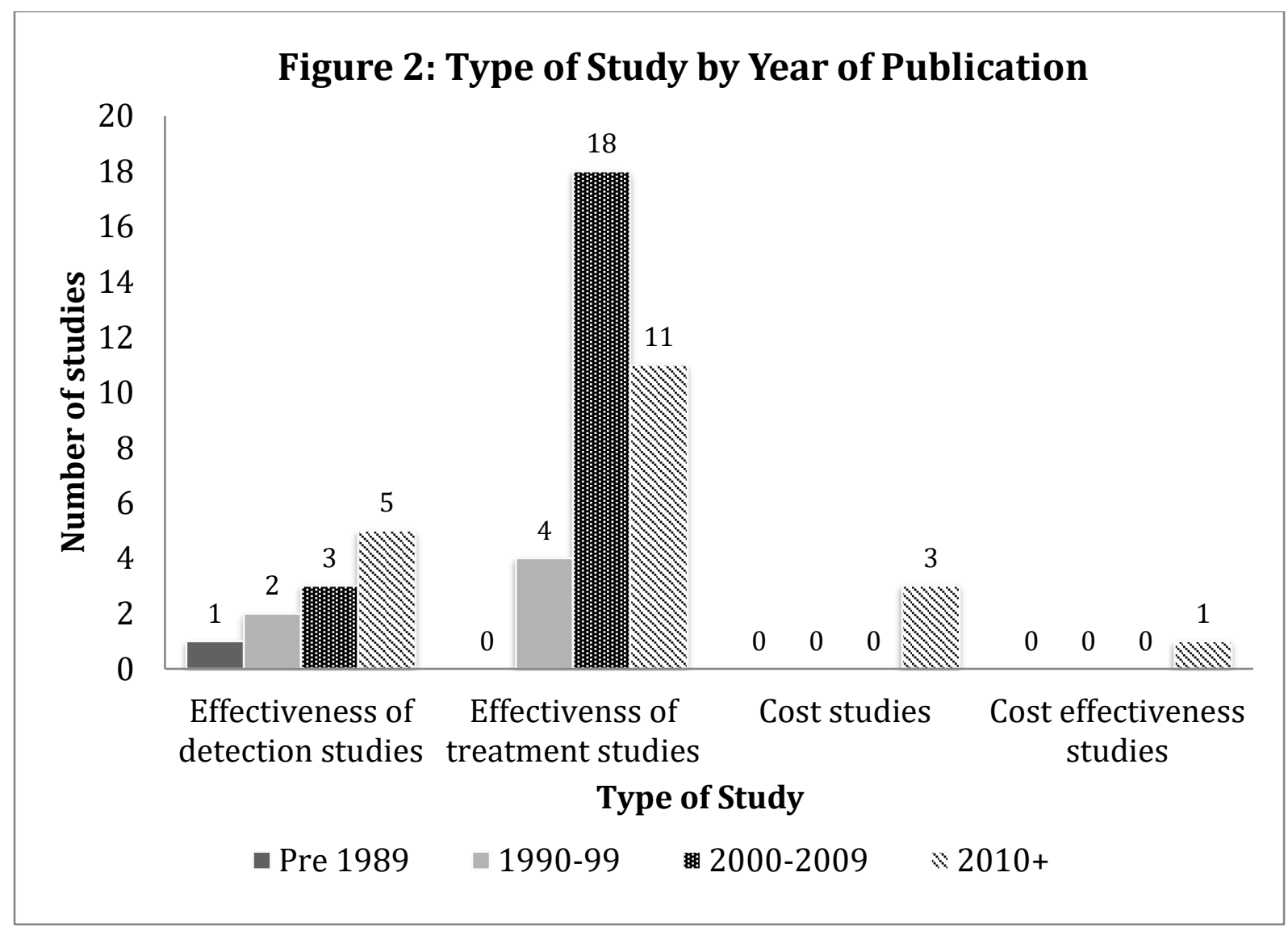




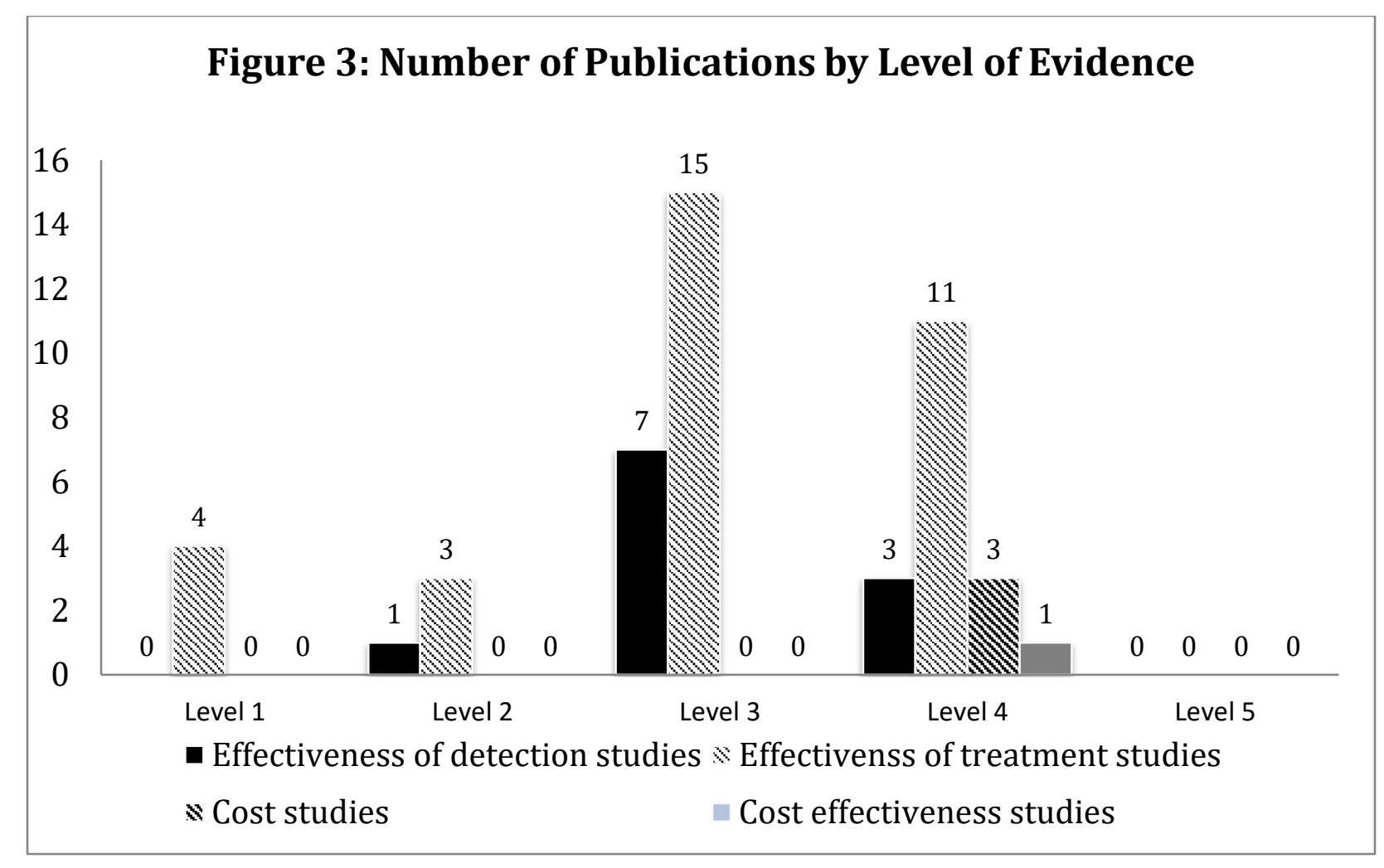




\section{Figure 4. Effect Size of Surgical Interventions for Glaucoma in SSA}

\begin{tabular}{|c|c|c|c|c|c|}
\hline \multirow[t]{2}{*}{ Studyname } & \multirow[b]{2}{*}{$\begin{array}{c}\text { Event } \\
\text { rate }\end{array}$} & \multicolumn{3}{|c|}{ Statistics for each study } & \multirow[b]{2}{*}{ p-Value } \\
\hline & & $\begin{array}{l}\text { Lower } \\
\text { limit }\end{array}$ & $\begin{array}{c}\text { Upper } \\
\text { limit }\end{array}$ & Z-Value & \\
\hline Krwan et al 2006 & 0.701 & 0.627 & 0.766 & 5.001 & 0.000 \\
\hline Yorston et al २001 & 0.299 & 0.233 & 0.375 & -4.880 & 0.000 \\
\hline Egbert et al 1993 & 0.667 & 0.376 & 0.869 & 1.132 & 0.258 \\
\hline Mwanza et al 2001 & 0.818 & 0.493 & 0.954 & 1.924 & 0.054 \\
\hline Mielke et al, 2006 & 0.222 & 0.086 & 0.465 & -2210 & 0.027 \\
\hline Girma et al 2006 & 0.387 & 0.235 & 0.565 & -1.246 & 0.213 \\
\hline Anand et al, 2001 & 0.852 & 0.784 & 0.902 & 7.408 & 0.000 \\
\hline Ashaye et al, 2009 & 0.783 & 0.662 & 0.870 & 4.101 & 0.000 \\
\hline Dahan et al, 2000 & 0.500 & 0.396 & 0.604 & 0.000 & 1.000 \\
\hline Grieshaber MC et al, 2010 & 0.783 & 0.662 & 0.870 & 4.101 & 0.000 \\
\hline Kimet al, 2008 & 0.567 & 0.388 & 0.729 & 0.728 & 0.467 \\
\hline Agbeja-Baiyeroju et al, 2001 & 0.550 & 0.502 & 0.596 & 2.063 & 0.039 \\
\hline Alemu 1997 & 0.789 & 0.750 & 0.824 & 11.678 & 0.000 \\
\hline Belibele 2001 & 0.732 & 0.602 & 0.832 & 3.332 & 0.001 \\
\hline Lawan 2007 & 0.972 & 0.894 & 0.993 & 4.937 & 0.000 \\
\hline Verryet al 1990 & 0.839 & 0.799 & 0.872 & 12084 & 0.000 \\
\hline Stegmann et al 1999 & 0.832 & 0.776 & 0.876 & 8.746 & 0.000 \\
\hline Olawoye et al 2013 & 0.830 & 0.695 & 0.913 & 4.081 & 0.000 \\
\hline Mielke et al, 2003 & 0.645 & 0.532 & 0.744 & 2.487 & 0.013 \\
\hline Adegbehingbe et al, 2007 & 0.611 & 0.495 & 0.716 & 1.870 & 0.062 \\
\hline Anand et al 2012 & 0.881 & 0.771 & 0.942 & 4.981 & 0.000 \\
\hline Quigley et al 2000 & 0.889 & 0.648 & 0.972 & 2773 & 0.006 \\
\hline Kabiru et al 2005 & 0.898 & 0.840 & 0.937 & 8.249 & 0.000 \\
\hline \multirow[t]{2}{*}{ Bowman et al 2010} & 0.854 & 0.769 & 0.912 & 6.113 & 0.000 \\
\hline & 0.702 & 0.683 & 0.720 & 19.278 & 0.000 \\
\hline
\end{tabular}

Event rate and $95 \% \mathrm{Cl}$

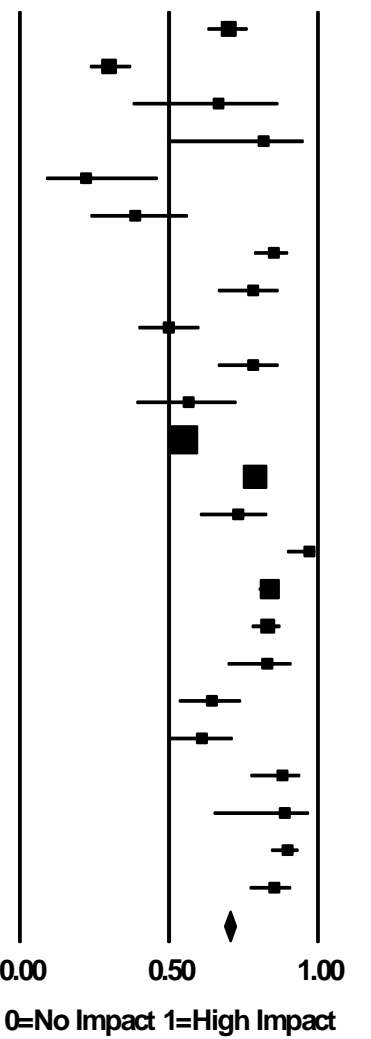

$0=$ No Impact 1=High Impact 
Table 1: Effectiveness of Detection Strategies for Glaucoma in Sub-Saharan Africa (n=11)

\begin{tabular}{|c|c|c|c|c|c|c|c|}
\hline Author & Country & Setting & $\begin{array}{l}\text { Number of } \\
\text { Participants (Eyes) }\end{array}$ & $\begin{array}{l}\text { Detection Strategy } \\
\text { Evaluated }\end{array}$ & $\begin{array}{l}\text { Effectiveness } \\
\text { Measure Used } \\
\end{array}$ & $\begin{array}{l}\text { Effectiveness of } \\
\text { Intervention }\end{array}$ & $\begin{array}{c}\text { Level of } \\
\text { Evidence }\end{array}$ \\
\hline $\begin{array}{l}\text { Munachonga et al } \\
2007[18]\end{array}$ & Tanzania & $\begin{array}{l}\text { Tertiary } \\
\text { eye care }\end{array}$ & 484 & $\begin{array}{l}\text { Ascertainment of first } \\
\text { degree relative history }\end{array}$ & $\begin{array}{l}\text { Provision of free eye } \\
\text { exam to FDR }\end{array}$ & $\begin{array}{l}\text { OR }=1.87 \text { for attending eye } \\
\text { exam if offered free of } \\
\text { charge, but low yield. Free } \\
\text { eye exams insufficient } \\
\text { incentive for an eye exam }\end{array}$ & 2 \\
\hline $\begin{array}{l}\text { Dean et al } 2012 \\
{[19]}\end{array}$ & Malawi & $\begin{array}{l}\text { Primary } \\
\text { health care }\end{array}$ & $\begin{array}{l}294 \text { persons screened } \\
\text { by nurse and } 147 \\
\text { referred to ophthalmic } \\
\text { clinical officer; } 56 \\
\text { referred to } \\
\text { ophthalmologist }\end{array}$ & $\begin{array}{l}\text { Pin hole visual acuity } \\
\text { of }>6 / 18 \text { and cup to disc } \\
\text { ratio of }>0.7 \text { using direct } \\
\text { ophthalmoscope }\end{array}$ & $\begin{array}{l}\text { Percent correctly } \\
\text { referred for definitive } \\
\text { ascertainment of } \\
\text { glaucoma status }\end{array}$ & $\begin{array}{l}\text { Only two }(0.68 \%) \text { patients } \\
\text { out of the original } 294 \\
\text { were found to have } \\
\text { glaucoma by } \\
\text { ophthalmologists. Poor } \\
\text { performance. }\end{array}$ & 3 \\
\hline Kok et al 1998 [20] & Nigeria & $\begin{array}{l}\text { Primary } \\
\text { health care }\end{array}$ & 864 patients & $\begin{array}{l}\text { Combination of pupil } \\
\text { exam, palpation, and } \\
\text { excavation as screening } \\
\text { tools for glaucoma }\end{array}$ & IOP & $\begin{array}{l}\text { None were found to be } \\
\text { effective replacements } \\
\text { (sensitivity's all }<80 \% \\
\text { even for IOP }>30 \mathrm{mmHg} \text { ). } \\
\text { Poor performance overall. }\end{array}$ & 3 \\
\hline Ashaye 2003 [21] & Nigeria & $\begin{array}{l}\text { Tertiary } \\
\text { care }\end{array}$ & $\begin{array}{l}240 \text { glaucoma cases } \\
250 \text { controls }\end{array}$ & $\begin{array}{l}\text { Peripheral Anterior } \\
\text { Chamber Depth (PACD) } \\
\text { and Central Anterior } \\
\text { Chamber Depth (CACD) }\end{array}$ & $\begin{array}{l}\text { Open or closed } \\
\text { angles }\end{array}$ & $\begin{array}{l}\text { PACD for PACG and } \\
\text { POAG: } \\
\text { Sn=77.8\%; Sp=82.4\% } \\
\text { CACD Primary glaucoma } \\
\mathrm{Sn}=58.3 \% ; \mathrm{Sp}=96.1 \% \\
\text { Overall good performance }\end{array}$ & 3 \\
\hline $\begin{array}{l}\text { Mahmoud et al } \\
2008 \text { [22] }\end{array}$ & Nigeria & $\begin{array}{l}\text { Tertiary } \\
\text { eye care }\end{array}$ & $\begin{array}{l}65 \text { glaucomatous eyes } \\
62 \text { control eyes }\end{array}$ & $\begin{array}{l}\text { Oculo-kinetic perimetry } \\
\text { glaucoma screening test } \\
\text { (OKPGST) versus } \\
\text { KOWA AP } 125 \\
\text { automatic central visual } \\
\text { field plotter }\end{array}$ & Visual field defects & $\begin{array}{l}\text { Performance: } \\
\mathrm{Sn}=93.8 \% \\
\mathrm{Sp}=96.8 \% \\
\text { Performed very well in } \\
\text { both clinic and rural } \\
\text { outreach setting }\end{array}$ & 3 \\
\hline $\begin{array}{l}\text { Foster et al } 1989 \\
{[23]}\end{array}$ & Ghana & $\begin{array}{l}\text { Primary } \\
\text { eye care }\end{array}$ & 100 eyes & $\begin{array}{l}\text { Direct ophthalmoscopy } \\
\text { by either an } \\
\text { Ophthalmologists, } \\
\text { General Practitioner or } \\
\text { Ophthalmic Nurse }\end{array}$ & $\begin{array}{l}\text { Inter-observer } \\
\text { agreement on: C/D } \\
\text { ratio, colour, } \\
\text { symmetry and } \\
\text { diagnosis }\end{array}$ & $\begin{array}{l}\text { Kappa Values (Reference } \\
\text { was an ophthalmologist) } \\
\text { For C/D ratios: } \\
\text { Ophthalmologist (0.92); } \\
\text { GP (074); } \\
\text { Ophthalmic nurse }(0.75) \\
\text { For Diagnosis of } \\
\text { Glaucoma: } \\
\text { Ophthalmologist }(0.81) \text {; } \\
\text { GP }(075) ; \\
\text { Ophthalmic nurse }(0.77)\end{array}$ & 3 \\
\hline
\end{tabular}




\begin{tabular}{|c|c|c|c|c|c|c|c|}
\hline $\begin{array}{l}\text { Kiage et al } 2013 \\
\text { [24] }\end{array}$ & Kenya & $\begin{array}{l}\text { Secondary } \\
\text { care }\end{array}$ & 309 patients & $\begin{array}{l}\text { Tele-glaucoma } \\
\text { assessment by glaucoma } \\
\text { specialist versus gold- } \\
\text { standard clinical } \\
\text { examination }\end{array}$ & $\begin{array}{l}\text { Frequency doubling } \\
\text { Vertical Cup to Disc } \\
\text { Ratio (VCDR) }\end{array}$ & $\begin{array}{l}\text { KappaValues (Reference } \\
\text { was an ophthalmologist): } \\
\text { Tele-glaucoma: } 0.55 \\
\text { Only moderate ability to } \\
\text { detect glaucoma, mainly } \\
\text { due to poor photographs }\end{array}$ & 3 \\
\hline $\begin{array}{l}\text { Onochie et al } 2016 \\
\text { [25] }\end{array}$ & Nigeria & $\begin{array}{l}\text { Tertiary } \\
\text { eye care }\end{array}$ & 75 patients & $\begin{array}{l}\text { Tono-pen versus } \\
\text { Goldmann applanation } \\
\text { tonometry (GAT) }\end{array}$ & $\begin{array}{l}\text { IOP mmHg } \\
\text { measurement }\end{array}$ & $\begin{array}{l}\text { Tono-pen tended to yield } \\
\text { higher IOP values than } \\
\text { GAT (p-value } 0.005 \text { ) but } \\
\text { was better tolerated by } \\
\text { patients than GAT }\end{array}$ & 3 \\
\hline $\begin{array}{l}\text { Quigley et al } \\
1993[26]\end{array}$ & Tanzania & $\begin{array}{l}\text { Primary } \\
\text { eye care }\end{array}$ & 120 patients & $\begin{array}{l}\text { Tono-pen tonometer, } \\
\text { direct ophthalmoscope, } \\
\text { laptop visual field and } \\
\text { scotopic sensitivity } \\
\text { testing }\end{array}$ & $\begin{array}{l}\text { IOP measures, Cup to } \\
\text { disc ratio, Visual } \\
\text { fields on laptop } \\
\text { computer }\end{array}$ & $\begin{array}{l}\text { Visual function tests could } \\
\text { be conducted on } 90 \% \text { of } \\
\text { patients and were } \\
\text { correlated with the size of } \\
\text { the optic disc cup, a } \\
\text { measure of glaucoma } \\
\text { injury. Good performance. }\end{array}$ & 4 \\
\hline $\begin{array}{l}\text { Giardini et al } 2014 \\
\text { [27] }\end{array}$ & Kenya & Eye study & $\begin{array}{l}300 \text { patients recruited } \\
\text { from ongoing eye study }\end{array}$ & $\begin{array}{l}\text { Dilated eye exam of the } \\
\text { fundus using a Smart } \\
\text { Phone camera }\end{array}$ & $\begin{array}{l}\text { Agreement between } \\
\text { Vertical Cup to Disc } \\
\text { Ratio using Fundus } \\
\text { Camera and Smart } \\
\text { Phone }\end{array}$ & $\begin{array}{l}\text { Excellent agreement in } \\
\text { VCDR between fundus } \\
\text { camera and Smart phone } \\
\text { ( } \mathrm{p}=0.98 \text { for no difference } \\
\text { in agreement between the } \\
\text { two) }\end{array}$ & 4 \\
\hline $\begin{array}{l}\text { Olawoye et al } 2013 \\
\text { [28] }\end{array}$ & Nigeria & $\begin{array}{l}\text { Tertiary } \\
\text { eye care }\end{array}$ & 653 patients & $\begin{array}{l}\text { Comparison of outreach } \\
\text { versus other referral } \\
\text { sources }\end{array}$ & $\begin{array}{l}\text { Severity of glaucoma } \\
\text { damage }\end{array}$ & $\begin{array}{l}\text { Patients from outreach } \\
\text { sources experienced more } \\
\text { mild to moderate } \\
\text { glaucoma and thus more } \\
\text { likely to benefit from early } \\
\text { intervention for glaucoma } \\
\text { vision loss and blindness }\end{array}$ & 4 \\
\hline
\end{tabular}


Table 2: Effectiveness of Treatment Strategies for Glaucoma in Sub-Saharan Africa (Assumes a random effects model, $\mathrm{n}=33$ )

\begin{tabular}{|c|c|c|c|c|c|c|c|}
\hline Author & Country & Setting & $\begin{array}{l}\text { Number of } \\
\text { Eyes }\end{array}$ & $\begin{array}{l}\text { Intervention } \\
\text { Evaluated }\end{array}$ & $\begin{array}{l}\text { Effectiveness } \\
\text { Measure Used }\end{array}$ & Effectiveness of Intervention & $\begin{array}{l}\text { Level of } \\
\text { Evidence }\end{array}$ \\
\hline \multicolumn{8}{|l|}{$\begin{array}{l}\text { Medical } \\
\text { Treatment } \\
\text { Strategies }(n=2)\end{array}$} \\
\hline $\begin{array}{l}\text { Koffuor et al } 2012 \\
\text { [29] }\end{array}$ & Ghana & $\begin{array}{l}\text { National } \\
\text { Health } \\
\text { Insurance } \\
\text { Scheme } \\
\text { (NHIS) }\end{array}$ & $\begin{array}{l}\text { Review of } 141 \\
\text { patients being } \\
\text { treated for } \\
\text { glaucoma using } \\
\text { both mono and } \\
\text { combination } \\
\text { anti-glaucoma } \\
\text { medications }\end{array}$ & $\begin{array}{l}\text { Efficacy of the } \\
\text { National Health } \\
\text { Insurance Scheme } \\
\text { listed anti-glaucoma } \\
\text { drugs in the } \\
\text { management of } \\
\text { primary open-angle } \\
\text { glaucoma in Ghana }\end{array}$ & IOP reduction & $\begin{array}{l}\text { Combination therapies involving } \\
\text { Latanoprost and listed anti- } \\
\text { glaucoma drugs reduced IOP } \\
\text { significantly than combination } \\
\text { therapies involving NHIS-listed } \\
\text { drugs only }(\mathrm{p} \leq 0.01) . \\
63 \% \text { reduction in IOP }<21 \mathrm{~mm} \mathrm{Hg} \\
\text { after eight visits to ophthalmologist }\end{array}$ & 3 \\
\hline $\begin{array}{l}\text { Tamrat et al } 2015 \\
{[30]}\end{array}$ & Ethiopia & $\begin{array}{l}\text { Tertiary eye } \\
\text { care }\end{array}$ & 200 patients & $\begin{array}{l}\text { Adherence to topical } \\
\text { anti-glaucoma } \\
\text { medications }\end{array}$ & $\begin{array}{l}\text { Non-adherence to } \\
\text { glaucoma therapy } \\
\text { (NAGT) }\end{array}$ & $\begin{array}{l}135(68 \%) \text { were deemed to be } \\
\text { NAGT }\end{array}$ & 4 \\
\hline Pooled effect size & & & 341 patients & & & $0.66(95 \%$ C.I. 0.61-0.71) & $\begin{aligned} Q & =0.70 \\
I^{2} & =0.00\end{aligned}$ \\
\hline \multicolumn{8}{|l|}{$\begin{array}{l}\text { Laser Treatment } \\
\text { Strategies }(n=4)\end{array}$} \\
\hline $\begin{array}{l}\text { Egbert et al, } 2001 \\
\text { [31] }\end{array}$ & Ghana & $\begin{array}{l}\text { Tertiary eye } \\
\text { care }\end{array}$ & $\begin{array}{l}79 \text { eyes } \\
\text { completing } \\
\text { follow-up }\end{array}$ & $\begin{array}{l}\text { Diode Laser trans- } \\
\text { scleral } \\
\text { cyclophotocoagulation } \\
\text { (TSCPC) }\end{array}$ & IOP reduction & $\begin{array}{l}38 \text { eyes }(48 \%) \text { had IOP }<22 \mathrm{mmHg} \\
\text { at } 3 \text { months }\end{array}$ & 2 \\
\hline $\begin{array}{l}\text { Schwering et al } \\
2013 \text { [32] }\end{array}$ & Malawi & $\begin{array}{l}\text { Tertiary eye } \\
\text { care }\end{array}$ & $\begin{array}{l}\text { Review of } \\
47 \text { eyes treated } \\
\text { with TSCPC } \\
\text { and } 18 \text { eyes } \\
\text { completing full } \\
\text { follow-up }\end{array}$ & $\begin{array}{l}\text { Transscleral } \\
\text { cyclophotocoagulation } \\
\text { (TSCPC) }\end{array}$ & IOP reduction & $\begin{array}{l}\text { After a single treatment session, } \\
\text { IOP decreased by } 25 \% \text { in } 88 \% \text { ( } 21 \\
\text { of } 24 \text { ) after } 2 \text { weeks, however, this } \\
\text { decreased to } 50 \% \text { (nine of 18) of } \\
\text { patients after } 3 \text { months. }\end{array}$ & 3 \\
\hline $\begin{array}{l}\text { Babalola, } 2015 \\
\text { [33] }\end{array}$ & Nigeria & $\begin{array}{l}\text { Tertiary eye } \\
\text { care }\end{array}$ & $\begin{array}{l}\text { Review of } 30 \\
\text { eyes }\end{array}$ & Laser trabeculosplasty & IOP reduction & $\begin{array}{l}5 \text { out of } 30 \text { or } 17 \% \text { decrease in IOP } \\
\text { post op }\end{array}$ & 4 \\
\hline $\begin{array}{l}\text { Mavrakanas et } \\
\text { al 2013[34] }\end{array}$ & Tanzania & $\begin{array}{l}\text { Tertiary eye } \\
\text { care }\end{array}$ & 49 eyes & $\begin{array}{l}\text { Diode laser } \\
\text { transscleral } \\
\text { cyclophotocoagulation } \\
\text { for the } \\
\text { treatment of glaucoma }\end{array}$ & IOP reduction & $\begin{array}{l}\text { Postoperative IOP was significantly } \\
\text { lower }(\mathrm{P}<0.01) \text {. } \\
\text { At the first postoperative visit, } \\
21 / 49(43 \%) \text { patients had } \\
\text { an IOP of } \leq 21 \mathrm{~mm} \mathrm{Hg}\end{array}$ & 4 \\
\hline Pooled effect size & & & 176 & & & $0.39(95 \%$ C.I. 0.27-0.54) & $\begin{array}{c}Q=8.54 \\
I^{2}=64.85\end{array}$ \\
\hline
\end{tabular}




\begin{tabular}{|c|c|c|c|c|c|c|c|}
\hline \multicolumn{8}{|l|}{$\begin{array}{l}\text { Surgical Treatment } \\
\text { with Valve } \\
\text { Implants }(n=3)\end{array}$} \\
\hline Giorgis 2012 [35] & Ethiopia & $\begin{array}{l}\text { Tertiary eye } \\
\text { care }\end{array}$ & $\begin{array}{l}13 \text { eyes } \\
\text { reviewed }\end{array}$ & $\begin{array}{l}\text { Ahmed Tube Shunt } \\
\text { Implants for refractory } \\
\text { adult glaucoma cases } \\
\end{array}$ & IOP reduction & $\begin{array}{l}77 \%(\mathrm{n}=10) \text { had IOP }<22 \mathrm{mmHg} \\
\text { post-operatively }\end{array}$ & 3 \\
\hline $\begin{array}{l}\text { Woodcock et al } 2008 \\
{[36]}\end{array}$ & South Africa & $\begin{array}{l}\text { Tertiary eye } \\
\text { care }\end{array}$ & $\begin{array}{l}157 \text { eyes } \\
\text { reviewed }\end{array}$ & Molteno implants & IOP reduction & $\begin{array}{l}\text { Complete success defined as an } \\
\text { IOP of } 6-22 \mathrm{mmHg} \text { with no } \\
\text { additional treatment was achieved } \\
\text { in } 30 \%(\mathrm{n}=47) \text { of eyes or }\end{array}$ & 3 \\
\hline Gessesse, 2015 [37] & Ethiopia & $\begin{array}{l}\text { Tertiary eye } \\
\text { care }\end{array}$ & $\begin{array}{l}\text { Review of } 12 \\
\text { eyes }\end{array}$ & $\begin{array}{l}\text { Ahmed valve } \\
\text { implantation }\end{array}$ & IOP reduction & $\begin{array}{l}67 \%(\mathrm{n}=8)<22 \mathrm{mmHg} 6 \text { months } \\
\text { post op }\end{array}$ & 4 \\
\hline Pooled effect size & & & 182 & & & $0.56(95 \%$ C.I. 0.23-0.84) & $\begin{array}{l}Q=14.02 \\
I^{2}=85.74\end{array}$ \\
\hline \multicolumn{8}{|l|}{$\begin{array}{l}\text { Surgical Treatment } \\
\text { Strategies } \\
\text { (Including the use } \\
\text { of Anti-metabolites) } \\
(n=24)\end{array}$} \\
\hline $\begin{array}{l}\text { Kirwan et al } 2006 \\
{[38]}\end{array}$ & South Africa & $\begin{array}{l}\text { Tertiary eye } \\
\text { care }\end{array}$ & $\begin{array}{l}320 \text { people } \\
156 \text { no } \\
\text { radiation } \\
164 \beta \text { radiation }\end{array}$ & $\begin{array}{l}\text { Trabeculectomy plus } \\
\beta \text {-radiation }\end{array}$ & IOP reduction & $\begin{array}{l}\text { Percent failing treatment at } 12 \\
\text { months defined as IOP > } 21 \\
\text { mmHg: } 30 \% \text { in placebo arm } \\
\text { versus } 5 \% \text { in treatment }(\beta- \\
\text { radiation) Success Rate: } 70 \%\end{array}$ & 1 \\
\hline $\begin{array}{l}\text { Yorston et al } 2001 \\
\text { [39] }\end{array}$ & $\begin{array}{l}\text { Kenya \& } \\
\text { Tanzania }\end{array}$ & $\begin{array}{l}\text { Tertiary eye } \\
\text { care }\end{array}$ & $\begin{array}{l}68 \text { eyes } \\
32 \text { FU } \\
36 \text { Controls }\end{array}$ & $\begin{array}{l}\text { 5-fluorouracil ( } 5 \text {-FU } \\
\text { with trabeculectomy } \\
\text { surgery }\end{array}$ & IOP reduction & $\begin{array}{l}\text { At } 24 \text { months } 5 \text {-FU had greater } \\
\text { success in IOP reduction }(<22 \\
\mathrm{mmHg}) 89 \% \text { to } 71 \% \text { in the } \\
\text { placebo group }\end{array}$ & 1 \\
\hline $\begin{array}{l}\text { Egbert et al } 1993 \\
{[40]}\end{array}$ & Ghana & $\begin{array}{l}\text { Tertiary eye } \\
\text { care }\end{array}$ & $\begin{array}{l}55 \text { eyes } \\
24 \text { eyes in } 5-\mathrm{FU} \\
\text { group } \\
31 \text { eyes in } \\
\text { control }\end{array}$ & Intra-operative 5-FU & IOP reduction & $\begin{array}{l}\text { Twenty of } 24 \text { eyes in } 5 \text {-FU group } \\
(83 \%) \text { and } 12 \text { of } 31 \text { eyes in control } \\
\text { group }(39 \%) \text { had post-operative } \\
\text { IOP } \leq 20 \mathrm{mmHg} \text { without medical } \\
\text { therapy }(\mathrm{p}=0.01)\end{array}$ & 1 \\
\hline $\begin{array}{l}\text { Mwanza et al } 2001 \\
\text { [41] }\end{array}$ & Congo & $\begin{array}{l}\text { Tertiary eye } \\
\text { care }\end{array}$ & $\begin{array}{l}22 \text { eyes } \\
11 \text { eyes MMC } \\
11 \text { eyes no } \\
\text { MMC }\end{array}$ & $\begin{array}{l}\text { Intraoperative } \\
\text { application of } \\
\text { mitomycin-C } \\
\text { during trabeculectomy }\end{array}$ & IOP reduction & $\begin{array}{l}\text { At } 20 \text { months success defined as an } \\
\text { IOP } \leq 21 \text { mmHg without anti- } \\
\text { glaucoma medications was } 81.8 \% \\
\text { and } 63.6 \% \text { respectively in eyes } \\
\text { treated with and without MMC }\end{array}$ & 1 \\
\hline $\begin{array}{l}\text { Mielke et al, } 2006 \\
{[42]}\end{array}$ & Nigeria & $\begin{array}{l}\text { Tertiary eye } \\
\text { care }\end{array}$ & $\begin{array}{l}39 \text { eyes } \\
21 \text { control } \\
\text { group } \\
18 \text { Intervention }\end{array}$ & $\begin{array}{l}\text { Deep sclerectomy } \\
\text { (DC) and DC plus } \\
\text { MMC }\end{array}$ & IOP reduction & $\begin{array}{l}24 \% \text { for DU with MMC and } 13 \% \\
\text { without MMC <18 mmHg at } \\
\text { 1year, but low power of study and } \\
\text { not statistically significant }\end{array}$ & 2 \\
\hline
\end{tabular}




\begin{tabular}{|c|c|c|c|c|c|c|c|}
\hline $\begin{array}{l}\text { Girma et al } 2006 \\
{[43]}\end{array}$ & Ethiopia & $\begin{array}{l}\text { Tertiary eye } \\
\text { care }\end{array}$ & $\begin{array}{l}31 \text { cases } \\
29 \text { controls }\end{array}$ & $\begin{array}{l}\text { Mitomycin } \mathrm{C} \text { in } \\
\text { Trabeculectomy }\end{array}$ & IOP reduction & $\begin{array}{l}\text { No statistically significant } \\
\text { difference in IOP, however, cases } \\
\text { had higher rate of complications } \\
\text { post-operatively } 12 \text { versus } 2 \text {. }\end{array}$ & 2 \\
\hline $\begin{array}{l}\text { Anand et al, } 2001 \\
{[44]}\end{array}$ & Nigeria & $\begin{array}{l}\text { Tertiary eye } \\
\text { care }\end{array}$ & $\begin{array}{l}142 \text { eyes in a } \\
\text { retrospective } \\
\text { review }\end{array}$ & Trabeculectomy & IOP reduction & $\begin{array}{l}85 \% \text { of eye had IOP }<22 \mathrm{mmHg} \text { at } \\
1 \text { year post op }\end{array}$ & 3 \\
\hline $\begin{array}{l}\text { Ashaye et al, } 2009 \\
{[45]}\end{array}$ & Nigeria & $\begin{array}{l}\text { Tertiary eye } \\
\text { care }\end{array}$ & $\begin{array}{l}60 \text { eyes } \\
\text { reviewed }\end{array}$ & Trabeculectomy & IOP reduction & $\begin{array}{l}79 \% \text { eyes has IOP }<21 \mathrm{mmHg} \text { at } 1 \\
\text { year post op }\end{array}$ & 3 \\
\hline $\begin{array}{l}\text { Dahan et al, } 2000 \\
\text { [46] }\end{array}$ & South Africa & $\begin{array}{l}\text { Tertiary eye } \\
\text { care }\end{array}$ & $\begin{array}{l}86 \text { eyes } \\
\text { reviewed in } \\
\text { total }\end{array}$ & Trabeculectomy & IOP reduction & $\begin{array}{l}50 \% \text { decrease in IOP }<21 \mathrm{~mm} \mathrm{Hg} \\
\text { post op at } 6 \text { months }\end{array}$ & 3 \\
\hline $\begin{array}{l}\text { Grieshaber MC et } \\
\text { al, } 2010 \text { [47] }\end{array}$ & South Africa & $\begin{array}{l}\text { Tertiary eye } \\
\text { care }\end{array}$ & $\begin{array}{l}\text { Review of } 60 \\
\text { eyes }\end{array}$ & $\begin{array}{l}360 \text { degree } \\
\text { viscodilation \& } \\
\text { canaloplasty }\end{array}$ & IOP reduction & $\begin{array}{l}78 \% \text { in } \mathrm{IOP}<21 \mathrm{mmHg} \text { at } 36 \\
\text { months }\end{array}$ & 3 \\
\hline $\begin{array}{l}\text { Kim et al, } 2008 \\
{[48]}\end{array}$ & Ghana & $\begin{array}{l}\text { Tertiary eye } \\
\text { care }\end{array}$ & $\begin{array}{l}\text { Review of } 68 \\
30 \text { on } \mathrm{MMC} \\
38 \text { on } 5-\mathrm{FU}\end{array}$ & MMC versus 5 -FU & IOP reduction & $\begin{array}{l}\text { MMC superior to } 5 \text {-FU ( } 55 \% \text { to } \\
24 \% \text { IOP }<21 \mathrm{mmHg}) \text { at } 6.5 \text { years }\end{array}$ & 3 \\
\hline $\begin{array}{l}\text { Agbeja-Baiyeroju } \\
\text { et al, 2001 [49] }\end{array}$ & Nigeria & $\begin{array}{l}\text { Tertiary eye } \\
\text { care }\end{array}$ & $\begin{array}{l}\text { Review of } \\
\text { operations on } \\
433 \text { eyes over a } \\
10 \text { year period }\end{array}$ & $\begin{array}{l}\text { Trabeculectomy } \\
\text { surgery }\end{array}$ & IOP reduction & $\begin{array}{l}55 \% \text { operated eyes had IOP }<21 \\
\text { mmHg by surgery alone }\end{array}$ & 3 \\
\hline Alemu 1997 [50] & Ethiopia & $\begin{array}{l}\text { Tertiary eye } \\
\text { care }\end{array}$ & $\begin{array}{l}\text { Review of } 470 \\
\text { eyes }\end{array}$ & $\begin{array}{l}\text { Trabeculectomy } \\
\text { surgery }\end{array}$ & IOP reduction & $\begin{array}{l}79 \% \text { of operated eyes had IOP < } \\
20 \mathrm{mmHg}\end{array}$ & 3 \\
\hline Bekibele 2001 [51] & Nigeria & $\begin{array}{l}\text { Tertiary eye } \\
\text { care }\end{array}$ & $\begin{array}{l}56 \text { eyes } \\
\text { reviewed }\end{array}$ & $\begin{array}{l}\text { Trabeculectomy } \\
\text { surgery }\end{array}$ & IOP reduction & $\begin{array}{l}74 \% \text { had IOP }<21 \mathrm{mmHg} \text { from } \\
\text { surgery alone and this increased to } \\
96 \% \text { with anti-glaucoma } \\
\text { medication post-operatively }\end{array}$ & 3 \\
\hline Lawan 2007 [52] & Nigeria & $\begin{array}{l}\text { Tertiary eye } \\
\text { care }\end{array}$ & $\begin{array}{l}71 \text { eyes } \\
\text { reviewed }\end{array}$ & $\begin{array}{l}\text { Trabeculectomy } \\
\text { surgery outcomes }\end{array}$ & IOP reduction & $\begin{array}{l}97 \% \text { of eyes had IOP }<20 \mathrm{mmHg} \\
\text { post-operatively }\end{array}$ & 3 \\
\hline $\begin{array}{l}\text { Verry et al } 1990 \\
{[53]}\end{array}$ & Ghana & $\begin{array}{l}\text { Tertiary eye } \\
\text { care }\end{array}$ & $\begin{array}{l}\text { Retrospective } \\
\text { review of } 397 \\
\text { patients }\end{array}$ & $\begin{array}{l}\text { Surgical intervention } \\
\text { for glaucoma }\end{array}$ & IOP reduction & $\begin{array}{l}\text { Of the patients treated surgically } \\
84 \% \text { of those seen at six months } \\
\text { had an lOP below } 22 \mathrm{mmHg} \text {. . }\end{array}$ & 3 \\
\hline $\begin{array}{l}\text { Stegmann et al } \\
1999[54]\end{array}$ & South Africa & $\begin{array}{l}\text { Tertiary eye } \\
\text { care }\end{array}$ & $\begin{array}{l}\text { Prospective } \\
\text { study of } 214 \\
\text { eyes }\end{array}$ & $\begin{array}{l}\text { Viscocanalostomy } \\
\text { for open-angle } \\
\text { glaucoma }\end{array}$ & IOP reduction & $\begin{array}{l}\text { IOP }<22 \mathrm{mmHg} \text { in } 83 \% \text { of eyes } \\
\text { IOP }<22 \mathrm{mmHg} \text { in } 89 \% \text { of eyes if } \\
\text { beta blocker added }\end{array}$ & 3 \\
\hline $\begin{array}{l}\text { Olawoye et al } 2013 \\
{[55]}\end{array}$ & Nigeria & $\begin{array}{l}\text { Tertiary eye } \\
\text { care }\end{array}$ & $\begin{array}{l}\text { Review of } 47 \\
\text { eyes }\end{array}$ & $\begin{array}{l}\text { Outcome of } \\
\text { trabeculectomy with } \\
\text { adjunctive } 5 \text { - } \\
\text { Fluorouracil (5-FU) }\end{array}$ & IOP reduction & $\begin{array}{l}\text { At } 12 \text { months post-operatively } 83 \% \\
\text { of eyes had a complete success } \\
\text { defined as an IOP of } \leq 18 \mathrm{mmHg} \\
\text { with no additional anti-glaucoma } \\
\text { medications }\end{array}$ & 4 \\
\hline
\end{tabular}




\begin{tabular}{|c|c|c|c|c|c|c|c|}
\hline $\begin{array}{l}\text { Mielke et al, } 2003 \\
{[56]}\end{array}$ & Nigeria & $\begin{array}{l}\text { Tertiary eye } \\
\text { care }\end{array}$ & $\begin{array}{l}\text { Review of } 154 \\
\text { eyes } \\
765 \text {-FU } \\
78 \text { Control }\end{array}$ & 5-FU versus controls & IOP reduction & $\begin{array}{l}64 \%<14 \mathrm{mmHg} \text { in } 5 \mathrm{FU} \text { versus } \\
\text { controls at } 18 \text { months }\end{array}$ & 4 \\
\hline $\begin{array}{l}\text { Adegbehingbe et } \\
\text { al, } 2007[57]\end{array}$ & Nigeria & $\begin{array}{l}\text { Tertiary eye } \\
\text { care }\end{array}$ & $\begin{array}{l}\text { Review of } 72 \\
\text { eyes }\end{array}$ & Trabeculectomy & IOP reduction & $\begin{array}{l}61.8 \%<20 \mathrm{mmHg} \text { at } 1 \text { year post- } \\
\text { op }\end{array}$ & 4 \\
\hline $\begin{array}{l}\text { Anand et al } 2012 \\
{[58]}\end{array}$ & Nigeria & $\begin{array}{l}\text { Tertiary eye } \\
\text { care }\end{array}$ & $\begin{array}{l}132 \text { eyes } \\
73 \text { eyes } 5 \text {-FU } \\
59 \text { eyes } \mathrm{MMC}\end{array}$ & $\begin{array}{l}\text { Efficacy and safety of } \\
\text { intraoperative 5- } \\
\text { fluorouracil (5-FU) or } \\
\text { mitomycin C (MMC) } \\
\text { in primary } \\
\text { trabeculectomy }\end{array}$ & IOP reduction & $\begin{array}{l}88 \% \text { in MMC group had } 1 \text { year IOP } \\
<19 \mathrm{mmHg} \\
\text { Postoperative IOPs were } \\
\text { significantly lower }(\mathrm{P}<0.05) \text { in the } \\
\text { MMC group at all follow up visits } \\
\text { except between } 30-35 \text { months } \\
(\mathrm{P}=0.07)\end{array}$ & 4 \\
\hline $\begin{array}{l}\text { Quigley et al } 2000 \\
\text { [59] }\end{array}$ & Tanzania & $\begin{array}{l}\text { Primary care } \\
\text { rural } \\
\text { Tanzania }\end{array}$ & $\begin{array}{l}\text { Review of } 18 \\
\text { patients from a } \\
\text { survey }\end{array}$ & $\begin{array}{l}\text { Surgical intervention } \\
\text { (iridectomy, } \\
\text { trabeculectomy, or } \\
\text { combined cataract } \\
\text { extraction/lens } \\
\text { implant/ } \\
\text { trabeculectomy) }\end{array}$ & IOP reduction & $\begin{array}{l}89 \% \text { (16 out of } 18) \text { eyes } \\
\text { undergoing trabeculectormy } \\
\text { achieving a reduction }>25 \% \text {. }\end{array}$ & 4 \\
\hline $\begin{array}{l}\text { Kabiru et al } 2005 \\
{[60]}\end{array}$ & Tanzania & $\begin{array}{l}\text { Tertiary eye } \\
\text { care }\end{array}$ & $\begin{array}{l}\text { Review of } 157 \\
\text { eyes }\end{array}$ & $\begin{array}{l}\text { Audit of } \\
\text { trabeculectomy } \\
\text { surgery }\end{array}$ & IOP reduction & $\begin{array}{l}90 \% \quad(141 / 157) \text { had intraocular } \\
\text { pressure of } \leq 21 \mathrm{~mm} \mathrm{Hg} .\end{array}$ & 4 \\
\hline $\begin{array}{l}\text { Bowman et al } 2010 \\
{[61]}\end{array}$ & Tanzania & $\begin{array}{l}\text { Tertiary ye } \\
\text { care }\end{array}$ & $\begin{array}{l}\text { Out of } 163 \\
\text { patients } \\
\text { identified, } 107 \\
\text { attended for } \\
\text { follow-up. Data } \\
\text { on } 96 \text { patients } \\
\text { was available } \\
\text { for follow-up } \\
\text { IOP } \\
\text { measurement } \\
\text { and on } 107 \\
\text { patients for } \\
\text { Visual Acuity } \\
\text { (VA) } \\
\text { assessment }\end{array}$ & $\begin{array}{l}\text { Combined cataract } \\
\text { and trabeculectomy } \\
\text { surgery for advanced } \\
\text { glaucoma }\end{array}$ & $\begin{array}{l}\text { IOP reduction } \\
\text { Visual Acuity }\end{array}$ & $\begin{array}{l}\text { IOP: } \\
\text { Fifty-nine }(62 \%) \text { patients had } \\
\text { follow-up IOPs of } 6-15 \mathrm{~mm} \mathrm{Hg} \\
82(85 \%) \text { had follow-up IOPs of } \\
6-20 \mathrm{~mm} \mathrm{Hg} \text {. } \\
\text { VA: } \\
75 \text { of } 107(70 \%) \text { patients had an } \\
\text { improved post-operative visual } \\
\text { acuity }\end{array}$ & 4 \\
\hline Pooled effect size & & & 2,937 & & & $0.73(95 \%$ C.I. 0.65-0.80) & $\begin{array}{c}Q=340.54 \\
I^{2}=93.25\end{array}$ \\
\hline
\end{tabular}


Table 3: Costs Associated with the Detection and Treatment of Glaucoma in Sub-Saharan Africa (n=3)

\begin{tabular}{|c|c|c|c|c|c|c|c|}
\hline Author & Country & Setting & $\begin{array}{l}\text { Number of } \\
\text { Participants }\end{array}$ & $\begin{array}{l}\text { Intervention } \\
\text { Evaluated }\end{array}$ & Direct Costs & Indirect Costs & $\begin{array}{l}\text { Level of } \\
\text { Evidence }\end{array}$ \\
\hline Adio et al 2012 [9] & Nigeria & $\begin{array}{l}\text { Tertiary } \\
\text { eye care }\end{array}$ & 120 patients & $\begin{array}{l}\text { Economic burden of } \\
\text { glaucoma }\end{array}$ & $\begin{array}{l}\text { Cost of glaucoma drugs } \\
\text { averaged US } \$ 40 / \text { month or } \\
\text { US } \$ 480 \text { per year }\end{array}$ & $\begin{array}{l}\text { Travel, labs, } \\
\text { companion costs US } \\
\$ 105 / \text { month or } \\
\text { US\$ } 1,260 \text { per year }\end{array}$ & 4 \\
\hline $\begin{array}{l}\text { Ocansey et al } 2016 \\
{[62]}\end{array}$ & Ghana & $\begin{array}{l}\text { Tertiary } \\
\text { eye care }\end{array}$ & $\begin{array}{l}891 \text { patients, but } \\
\text { only } \\
84 \text { adhered to all } \\
\text { visits }\end{array}$ & $\begin{array}{l}\text { Cost of medical } \\
\text { management }\end{array}$ & $\begin{array}{l}\text { Direct medication costs were } \\
\text { US \$ } 36,097 \text { per year among } \\
\text { the } 84 \text { who adhered to all } \\
\text { visits (US \$ } 429 \text { per patient } \\
\text { per year) and Direct non- } \\
\text { medication costs (surgery \& } \\
\text { tests costs) were US\$ } 4,523 \\
\text { per year or US\$ } 54 \text { per patient } \\
\text { per year. This yields a total } \\
\text { direct cost of US \$ } 483 \text { per } \\
\text { patient per year. }\end{array}$ & $\begin{array}{l}\text { Travel costs for } 84 \\
\text { patients who adhered } \\
\text { to all visits for } \\
\text { glaucoma } \\
\text { management } \\
\text { amounted to US } \\
\text { \$ } 484 \text { per year }\end{array}$ & 4 \\
\hline $\begin{array}{l}\text { Omoti et al } 2010 \\
{[8]}\end{array}$ & Nigeria & $\begin{array}{l}\text { Tertiary } \\
\text { eye care }\end{array}$ & 108 patients & $\begin{array}{l}\text { Cost of medical and } \\
\text { surgical treatment for } \\
\text { glaucoma }\end{array}$ & $\begin{array}{l}\text { Cost of medical treatment: } \\
\text { US\$ } 273 \text { per patient per year; } \\
\text { Cost of surgical treatment: } \\
\text { US\$ } 283 \text { per patient per year }\end{array}$ & Not given & 4 \\
\hline Mean Costs & & & & & $\begin{array}{l}\text { Mean Drug Costs per year: } \\
\text { US\$ } 394(n=3) \\
\text { Mean Direct non-Medication } \\
\text { costs per year: } \\
\text { US\$ 54 }(n=1) \\
\text { Mean Surgical Costs Per } \\
\text { Year: } \\
\text { US \$ } 283(n=1)\end{array}$ & $\begin{array}{l}\text { Mean Indirect Costs } \\
\text { per year: } \\
\text { US\$ } 872(n=2)\end{array}$ & \\
\hline
\end{tabular}


Table 4: Cost-Effectiveness of Various Detection and Treatment Modalities for Glaucoma in Sub-Saharan Africa (n=1)

\begin{tabular}{|c|c|c|c|c|c|c|}
\hline Author & Country & Setting & $\begin{array}{l}\text { Number of } \\
\text { Participants }\end{array}$ & Intervention Evaluated & Cost-Effectiveness Calculations & Level of Evidence \\
\hline $\begin{array}{l}\text { Wittenborn et al } \\
2011 \text { [63] }\end{array}$ & Ghana & Country wide & $\begin{array}{l}\text { Entire population } \\
\text { modelled }\end{array}$ & $\begin{array}{l}\text { Computer modelling of } \\
\text { case-finding and } \\
\text { treatment scenarios, } \\
\text { including a US } \\
\text { guideline-level care and } \\
\text { one-time laser surgery to } \\
\text { treat glaucoma }\end{array}$ & $\begin{array}{l}\text { Cost per DALY averted*: } \\
\text { Scenarios } \\
\text { A) Diagnosis on incidence } \\
\text { Guideline care: US } \$ 6,896 \text { per DALY } \\
\text { Laser only: US \$ } 1,771 \text { per DALY } \\
\text { B) Syndromic referral } \\
\text { Guideline care: US } \$ 3,947 \\
\text { Laser only: US } \$ 1,407 \\
\text { C) Universal Screening } \\
\text { Guideline care US\$ } 13,504 \\
\text { Laser only US } \$ 9,808\end{array}$ & 4 \\
\hline
\end{tabular}

*Cost Per Disability Adjusted Life Year (DALY) averted 


\section{Acknowledgements}

\section{Funding}

Funding for this study was provided by the British Council for the Prevention of Blindness, London, England.

\section{$\underline{\text { Disclosures }}$}

At the time of this research both AFS and AM were employees of MedMetrics Inc.

\section{Contributions}

AFS: Overall design, development and implementation of the entire research project, including review and comment on literature search strategies, extraction of data from the literature, reporting of findings, data analysis and preparation of manuscript

GN: Data searches, data extraction, collection and refinement of search results and review of papers. Input into manuscript preparation.

DB: Designing and carrying out literature search strategies. Managed the retrieved search results including removing duplicate records and finding from PDF files. Input into manuscript preparation.

IEM: Review and comment on literature search strategies, development and refinement of search results and involvement in manuscript preparation and revision.

HB: Review and comment on the literature searches results, as well as input into the manuscript.

KD: Review and comment on the literature searches results, as well as input into the manuscript.

AM: Data searches, data extraction, collection and refinement of search results and review of papers, aggregation of data and reporting of findings as well as input into manuscript preparation. 


\section{References:}

[1] Tham YC, Li X, Wong TY, Quigley HA, Aung T, Cheng CY. Global prevalence of glaucoma and projections of glaucoma burden through 2040: a systematic review and meta-analysis. Ophthalmology. 2014;121:2081-2090

[2] Quigley HA, Broman AT. The number of people with glaucoma worldwide in 2010 and 2020. $\mathrm{Br}$ J Ophthalmol, 2006;90:262-267

[3] Lewallen S, Hassan H, Al Attas AH, Courtright P, A population-based study of care-seeking behaviour in rural Tanzanians with glaucoma blindness. J-Glaucoma 2011; 20:361-365

[4] Abdull MM, Gilbert C, Evans J. Primary open angle glaucoma in northern Nigeria: stage at presentation and acceptance of treatment BMC Ophthalmology, 2015; 15:111

[5] Palmer JJ, Chinanayi F, Gilbert A, et al Mapping human resources for eye health in 21 countries of sub-Saharan Africa: current progress towards VISION 2020. Hum Resour Health. 2014; 12: 44. doi: $10.1186 / 1478-4491-12-44$

[6] http://data.worldbank.org/indicator/SP.RUR.TOTL.ZS ?locations=ZG Accessed $4^{\text {th }}$ May 2017

[7] http://data.worldbank.org/indicator/NY.GNP.PCAP.CD?locations=ZG Accessed 4 ${ }^{\text {th }}$ May 2017

[8] Omoti AE, Edema OT, Akpe BA, Musa P. Cost Analysis of Medical versus Surgical Management of Glaucoma in Nigeria. J Ophthalmic Vis Res. v.5(4); 2010

[9] Adio AO, Onua AA, Economic burden of glaucoma in Rivers State, Nigeria. Clin Ophthalmol. 2012; 6: 2023-2031.

[10] Shining a spotlight on glaucoma, The Lancet, 2009; 373 (4): 868

[11] http://data.worldbank.org/region/sub-saharan-africa Accessed 5th May 2017

[12]http://www.cebm.net/oxford-centre-evidence-based-medicine-levels-evidence-march-2009/ Accessed $23^{\text {rd }}$ January 2017

[13] Cochran WG. The comparison of percentages in matched samples. Biometrika, 1950: (3-4): 256266

[14] Gavaghan DJ, Moore AR, McQuay HJ. An evaluation of homogeneity tests in meta-analyses in pain using simulations of individual patient data. Pain 2000(3): 415-424

[15] Higgins JPT, Thompson SG, Deeks JJ, Altman DG. Measuring inconsistency in meta-analyses BMJ 2003; 327:557-560 
[16] Higgins JPT, Thompson SG. Quantifying heterogeneity in a meta-analysis Statist. Med. 2002; 21:1539-1558

[17] https://www.meta-analysis.com/ Accessed 5 ${ }^{\text {th }}$ September 2017

[18] Munachonga EM, Hall EB, Courtright P. Examination of First-Degree relatives of patients with glaucoma: a randomized trial of strategies to increase use in an eye hospital in Africa. Ophthalmic Epidemiology 2007; 14: 155-159

[19] Dean WH, Courtright P, Cook C. Does training clinic nurses to test pinhole visual acuity as a screen for glaucoma increase glaucoma referrals to eye care professionals? A pilot study in Malawi Ophthalmic Epidemiology 2012; 19(5):293-296

[20] Kok M, Berendschot TTJM, Hardus P. Schiotz tonometry for glaucoma: are there simple alternatives? Tropical Medicine and International Health 1998; 3(5):210-213

[21] Ashaye AO Use of limbal and central anterior chamber depth measurements in detecting eyes with gonioscopically occludale angles and primary angle closure glaucoma in Ibadan Afr. J. Med. Med. Sci. 2003; 32:413-416

[22] Mahmoud AO, Omalase CO, Ekundayo K. Evaluation of the Oculo-kinetic perimetry glaucoma screening test in a Sub-Saharan African setting. West African Journal of Medicine, 2008; 27(3): 134138

[23] Foster A, Wormald R, van de Heida A, Templeton K, Minassian D. Evaluation of ophthalmoscopy by non-ophthalmologists in diagnosis chronic glaucoma in West Africa. Eye; 1989;3:647-650

[24] Kiage D, Kherani I, Gichuhi S, Damji KF, Nyenze M. The Muranga teleophthalmology study: comparison of virtual (teleglaucoma) with in-person clinical assessment to diagnose glaucoma? Middle East Afr J Ophthalmol 2013;20:150-157

[25] Onochie C, Okoye O, Ogunro A, Aribaba T, Hassan K, Onakoya A. Comparison of the TonoPen ${ }^{\circledR}$ and Goldmann applanation tonometer in the measurement of intra-ocular pressure of primary open angle glaucoma patients in a hospital population in Southwest Nigeria. Med Princ Pract 2016;25:566-571

[26] Quigley HA, West SK, Munoz B, Mmbaga BBO, Glovinsky Y. Examination of methods for glaucoma prevalence surveys Arch Ophthalmol 1993; 111:1409-1415

[27] Giardini ME, Livingstone IA, Jordan S, Bolster NM, Peto T, Burton M, Bastawrous A. A smartphone based ophthalmoscope. Conf Proc IEEE Eng Med Biol Soc. 2014; 2014:2177-2180

[28] Olawoye O, Fawole OI, Teng CC, Ritch R. Evaluation of community eye outreach programs for early glaucoma detection in Nigeria Clinical Ophthalmology 2013:7 1753-1759 
[29] Koffuor GA, Ababio-Danso B, Gyanfosu L, Amoateng P. The efficacy of NHIS-listed antiglaucoma drugs in management of primary open-angle glaucoma Journal of Medical and Biomedical Sciences, 2012: 1(2):50-58

[30] Tamrat L, Gessesse GW, Gelaw Y. Adherence to topical glaucoma medications in Ethiopian patients. Middle East Afr J Ophthalmol 2015;22:59-63

[31] Egbert PR, Fiadoyor S, Budenz DL, Dadzie P, Byrd S. Diode laser transscleral cyclophotocoagulation as a primary surgical treatment for primary open-angle glaucoma Arch Ophthalmol 2001; 119:345-350

[32] Schwering MS, Kayange P, Klauss V, Kalua K, Spitzer MS. Low-dose transscleral diode laser cyclophotocoagulation (TSCPC) as a potential single treatment for primary open-angle glaucoma (POAG) in Malawi? Graefes Arch Clin Exp Ophthalmol 2013: 251:2389-2393

[33] Babalola OE. Micropulse diode laser trabeculoplasty in Nigerian patients Clinical Ophthalmology 2015; 9:1347-1351

[34] Mavrakanas N, Dhalla K, Kapesa I, Alihai A, Murdoch I. Diode laser transscleral cyclophotocoagulation for the treatment of glaucoma in East Africa Eye 2013;27:453-456

[35] Giorgis AT. Initial clinical experience of tube-shunt surgery in Ethiopian patients with refractory glaucoma Ethiop Med J. 2012; 50(2): 159-165

[36] Woodcock MGL, Richards JC, Murray AND. The last 11 years of Molteno implantation at the University of Cape Town. Refining our indications and surgical techniques Eye 2008; 22:18-25

[37] Gessesse GW. The Ahmed glaucoma valve in refractory glaucoma: experiences in Southwest Ethiopia Ethiop J Health Sci. 2015;25(3):267-272

[38] Kirwan JF, Cousens S, Venter L, Cook C, Stuling A, Roux P, Murdoch I. Effect of $\beta$ radiation on success of glaucoma drainage surgery in South Africa: randomised controlled trial BMJ. 2006; 333: $942-944$

[39] Yorston D, Khaw PT. A randomised trial of the effect of intraoperative 5-FU on the outcome of trabeculectomy in East Africa. Br J Ophthalmol 2001; 85:1028-1030

[40] Egbert PR, Williams AS, Singh K, Dadzie P, Egbert TB. A prospective trial of intraoperative Fluorouracil during trabeculectomy in a Black population. Am J Ophthalmol 1993; 116: 612-616

[41] Mwanza J-CK, Kabasele PM. Trabeculectomy with and without mitomycin-C in a black African population Eur J Ophthalmol 2001; 11:261-263

[42] Mielke C, Dawda VK, Anand N. Deep sclerectomy and low dose mitomycin C: a randomised prospective trial in west Africa Br J Ophthalmol 2006; 90:310-313 
[43] Girma T, Courtright P, Mengistu F, Tamirat T, Birhanu Z. A placebo controlled double blind clinical trial of mytomycin C in primar trabeculectomy in Ethiopian patient Ethiop Med J 44(3): 253256

[44] Anand N, Mielke C, Dawda VK. Trabeculectomy outcomes in advanced glaucoma in Nigeria Eye, 2001; 15:274-278

[45] Ashaye Ao, Komolafe OO. Post-operative complication of trabeculectomy in Ibadan, Nigeria: outcome of 1-year follow-up Eye 2009; 23:448-452

[46] Dahan E, Drusedau MUH. Nonpentrating filtration surgery for glaucoma: control by surgery only. J Cataract Refract Surg 2000; 26:695-701

[47] Grieshaber MG, Pienaar A, Olivier J, Stegmann R. Canaloplasty for primary open=angle glaucoma: long-term outcome. Br J Ophthalmol 2010; 94:1478-1482

[48] Kim H, Egbert PR, Singh K. Long-term comparison of primary trabeculectomy with 5Fluorouracil versus Mitomycin C in West Africa J Glaucoma 2008; 17:578-583

[49] Agbeja-Baiyeroju AM, Omoruyi M, Owoaje ET. Effectiveness of trabeculectomy on glaucoma patients in Ibadan. Afr. J.Med.med. Sci 2001; 30:39-42

[50] Alemu B. Trabeculectomy: complications and success in IOP control Ethiop Med J 1997:25: 111

[51] Bekibele CO. Evaluation of 56 trabeculectomy operations at Ago-Iwoye, Ogun State, Nigeria. WAJM 2001; 20(3):223-226

[52] Lawan A. Pattern of presentation of outcome of surgical management of primary open angle glaucoma in Kano, Northern Nigeria Annals of African Medicine 2007; 6(4):180-185

[53] Verry JD, Foster A, Wormald R, Akuamoa C. Chronic Glaucoma in Northern Ghana-A retrospective study of 397 patients Eye 1990: 4:115-120

[54] Stegmann R, Pienaar A, Miller D. Viscocanalostomy for open-angle glaucoma in black African patient's J Cataract Refract Surg 1999; 25:316-322

[55] Olawoye OO, Ashaye OA, Baiyeroju AM, Teng CC, Liebmann JM, Ritch R. Outcomes of trabeculectomy with 5-Fluorouracil at a Nigerian tertiary hospital. J Ophthalmic Vis Res 2013; $8(2): 126-133$

[56] Mielke C, Dawda VK, Anand N. Intraoperative 5-Fluorouracil application during primary trabeculectomy in Nigeria: a comprehensive study Eye 2003; 17:829-834

[57] Adegbehingbe BO, Majemgbasan T. A review of trabeculectomies at a Nigerian teaching hospital Ghana Medical Journal 2007; 41(4):176-180 
[58] Anand N, Dawda VK. A comparative study of mitomycin C and 5-fluorouracil trabeculectomy in West Africa. Middle East Afr J Ophthalmol 2012;19:147-152

[59] Quigley HA, Buhrmann RR West SK, Isseme I, Scudder M, Oliva MS. Long term results of glaucoma surgery among participants in an east African population survey. $\mathrm{Br}$ J Ophthalmol 2000; $84: 860-864$

[60] Kabiru J, Bowman R, Wood M, Mafwiri M. Audit of trabeculectomy at a tertiary referral hospital in East Africa J Glaucoma 2005; 14: 432-434

[61] Bowman RJC, Hay A, Wood ML, Murdoch IE. Combined cataract and trabeculectomy surgery for advanced glaucoma in East Africa; visual and intra-ocular pressure outcomes. Eye 2010; 24:573577

[62] Ocansey S, Kyei S, Diafo A, Darfor KN, Boadi-Kusi SB, Aglobitse PR. Cost of the medical management and prescription pattern for primary open angle glaucoma (POAG) in Ghana-a retrospective cross-sectional study from three referral facilities BMC Health Services Research 2016; $16: 282$

[63] Wittenborn JS Cost-effectiveness of glaucoma interventions in Barbados and Ghana Optom Vis Sci 2011;88:155-163

[64] Thomas S, Hodge W, Malvankar-Mehta M. The cost-effectiveness analysis of teleglaucoma screening device. PLoS One, 2015; 18;10(9):e0137913

[65] John D, Parikh R. Cost-effectiveness and cost utility of community screening for glaucoma in urban India. Public Health, 2017; 148:37-48

[66] Strouthidis NG, Chandrasekharan G, Diamond JP, Murdoch IE. Teleglaucoma: ready to go? $\mathrm{Br}$ J Ophthalmol 2014; 98:1605-11

[67] Vass C, Hirn C, Sycha T, Findl O, Bauer P, Schmetterer L. Medical interventions for primary open angle glaucoma and ocular hypertension. Cochrane Database Syst Rev. 2007;(4):CD003167.

[68] Chung PY, Schuman JS, Netland PA, Lloyd-Muhammad RA, Jacobs DS. Five-year results of a randomized, prospective, clinical trial of diode vs argon laser trabeculoplasty for open-angle glaucoma. Am J Ophthalmol. 1998;126(2):185-90

[69] Bergeå B, Bodin L, Svedbergh B. Primary argon laser trabeculoplasty. III. Long term effects on visual fields. Acta Ophthalmol Scand. 1995;73:207-215

[70] Glaucoma Laser Trial Research Group (1995): The Glaucoma Laser Trial (GLT) and Glaucoma Laser Trial Follow-up Study. 7. Results. Am J Ophthalmo. 1995;120:718-731 
[71] Knape RM, Szymarek TN, Tuli SS, Driebe WT, Sherwood MB, Smith MF. Five-year Outcomes of Eyes with Glaucoma Drainage Device and Penetrating Keratoplasty. Journal of Glaucoma. 2012;21(9):608-614

[72] Gedde SJ, Schiffman JC, Feuer WJ, Herndon LW, Brandt JD, Budenz DL. Tube versus Trabeculectomy Study Group. Treatment outcomes in the Tube Versus Trabeculectomy (TVT) study after five years of follow-up. Am J Ophthalmology. 2012; 153(3): 789-803

[73] Ehrnrooth P, Lehto I, Puska P, Laatikainen L. Long-term outcome of trabeculectomy in terms of intraocular pressure. Acta Ophthalmol Scand. 2002; 80(3):267-71

[74] http://www.who.int/medicines/publications/essentialmedicines/20th_EML2017.pdf?ua=1 Accessed $4^{\text {th }}$ September 2017

[75] Nayak B, Gupta S, Kumar G, Dada T, Gupta V, Sihota R. Socioeconomics of long-term glaucoma therapy in India. India J Ophthalmol. 2015; 63(1):20-4

[76] Lazcano-Gomez G, Ramos-Cadena M de los A, Torres-Tamayo M, Hernandez de Oteyza A, Turati-Acosta M, Jimenez-Román J. Cost of glaucoma treatment in a developing country over a 5year period. Villani. E, ed. Medicine. 2016;95(47):e5341

[77] Schehlein EM, Im LT, Robin AL, Onukwugha E, Saeedi OJ. Nonmedical Out-of-Pocket Patient and Companion Expenditures Associated with Glaucoma Care. J Glaucoma. 2017; 26(4): 343-348

[78] Personal email correspondence, AuroLab, Madurai, India. $14^{\text {th }}$ February 2018

[79] https://data. worldbank.org/indicator/NY.GDP.PCAP.CD?end=2011\&locations=GH\&start= 1960 Accessed $4^{\text {th }}$ September 2017

[80] Azuara-Blanco A, Burr J, Ramsay C, Cooper D, Foster PJ, Friedman DS, Scotland G, Javanbakht M, Cochrane C, Norrie J; EAGLE study group. Effectiveness of early lens extraction for the treatment of primary angle-closure glaucoma (EAGLE): a randomised controlled trial. Lancet. 2016; 388(10052):1389-1397

[81] Azuara-Blanco A, Banister K, Boachie C, McMeekin P, Gray J, Burr J, Bourne R, Garway-Heath D, Batterbury M, Hernádez R, McPherson G, Ramsay C, Cook J. Automated imaging technologies for the diagnosis of glaucoma: a comparative diagnostic study for the evaluation of diagnostic accuracy, performance as triage tests and cost-effectiveness (GATE study. Health Technol Assess. $2016 ; 20(8): 1-168$ 